\title{
Early to Late Bajocian age of the "black flysch" (Szlachtowa Fm.) deposits: implications for the history and geological structure of the Pieniny Klippen Belt, Carpathians
}

\author{
Marcin BARSKI, Bronisław Andrzej MATYJA, Tomasz SEGIT \\ and Andrzej WIERZBOWSKI
}

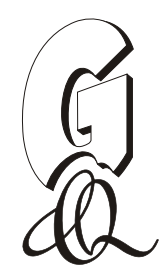

\begin{abstract}
Barski M., Matyja B.A., Segit T. and Wierzbowski A. (2012) - Early to Late Bajocian age of the "black flysch" (Szlachtowa Fm.) deposits: implications for the history and geological structure of the Pieniny Klippen Belt, Carpathians. Geol. Quart., 56 (3): 391-410, doi: $10.7306 /$ gq. 1030

The "black flysch" deposits (Szlachtowa Formation at Podubocze near Czorsztyn in Poland), attributed so far to the Pieniny Klippen Basin successions, and at Hałuszowa in Poland as well as at Kamienka in Eastern Slovakia, attributed to the Grajcarek Succession of the Magura Basin, have yielded rich dinoflagellate cyst assemblages consisting of forms both redeposited (from Upper Triassic to Aalenian) and indigenous (Lower Bajocian to Upper Bajocian). An Early to Late Bajocian age of the deposits investigated is thus indicated, and this along with other stratigraphical, sedimentological and tectonic data indicates that all the deposits in question represent the early stages of development of the Magura Basin. The formation of "black flysch" deposits was possibly related to the Early Bajocian uplift of the Czorsztyn Ridge which resulted from the opening of the Magura Ocean. The occurrence of the deposits of the Magura Basin below the overthrusted deposits of the Klippen Basin (Czorsztyn Unit) in the area of study results in a marked change in the structural interpretation of the Pieniny Klippen Belt.
\end{abstract}

Marcin Barski, Bronisław Andrzej Matyja and Tomasz Segit, Institute of Geology, University of Warsaw, wirki i Wigury 93, 02-089 Warszawa,Poland, e-mails: marbar@uw.edu.pl, matyja@uw.edu.pl, t.segit@uw.edu.pl; Andrzej Wierzbowski, Institute of Geology, University of Warsaw, wirki i Wigury 93,02-089 Warszawa, Poland, e-mail: andrzej.wierzbowski@uw.edu.pl; Polish Geological Institute - National Research Institute, Rakowiecka 4,00-975 Warszawa, Poland; e-mail: andrzej.wierzbowski@pgi.gov.pl (received: December 23, 2011; accepted: April 12, 2012; first published online: July 9, 2012)

Key words: Pieniny Klippen Belt, "black flysch”, stratigraphy, dinoflagellate cyst, palaeogeography, Magura Basin.

\section{INTRODUCTION}

The deposits of the "black flysch" facies represented by black micaceous shales with thin intercalations of sandstones were described from the Pieniny Klippen Belt in Poland (Fig. 1) by Horwitz (1926) and Horwitz and Rabowski (1930); these authors placed the deposits in their Pieniny Nappe succession, referred with reservation to the Lower Cretaceous, and called them the "Black Cretaceous". This opinion was questioned by Andrusov (1929) who, in deposits from the Orava area of Slovakia that he correlated with the "Black Cretaceous" of the Pieniny Klippen Belt, found ammonites and bivalves of Middle Jurassic age. Horwitz $(1933,1937)$ therefore placed the deposits in question in the Jurassic and called them the "Dogger Flysch".
Birkenmajer (1953, 1957a, b) referred the deposits to the "Flysch Aalenian" and originally placed them in the Pieniny Basin successions (especially the Branisko Succession) only, but later (Birkenmajer, 1977) in the Magura Basin (Grajcarek Succession) also, and established a new name for the lithostratigraphic unit - the Szlachtowa Formation - for all these deposits. Independently the deposits in question ("black flysch" - after Blaicher and Sikora, 1969) were subdivided into the Sztolnia Beds placed in the Hulina Succession representing the Magura Basin north of the "Geoanticlinal Pieniny Zone" (Sikora, 1962, 1971), and the Trawne Beds placed in the Zlatne Succession deposited in the southernmost part of the Pieniny Klippen Basin (Sikora, 1971; Blaicher and Sikora, 1972).

There are two different current, deeply entrenched opinions on the age of "black flysch" deposits in the Pieniny Klippen Belt. According to Birkenmajer $(1977,2001)$ these are Jurassic 
deposits (Upper Toarcian to Lower Aalenian). The opinion was corrected by Birkenmajer et al. (2008), who regarded the age of "black flysch" (the Szlachtowa Fm. of Birkenmajer, 1977) as Toarcian-Bajocian, but this was modified by Gedl (2008a) according to whom the bulk of the sections of "black flysch" studied by him (including those at Podubocze near Czorsztyn) represents Upper Aalenian-Lower Bajocian; the opinion was later markedly revised (Gedl, 2008b), and a wider stratigraphical interval was proposed for the deposits in question: from Upper Toarcian to Lower Bajocian in the Branisko Succession, and from Upper Toarcian to Upper Bajocian in the Grajcarek Succession, but with a "suggested hiatus" representing the Lower and Middle Aalenian.

On the other hand, according to Blaicher and Sikora (1969, 1972), the age of the "black flysch" as recognized by them in the Hulina and Zlatne successions (the Sztolnia Beds and the Trawne Beds, respectively) is Cretaceous. A similar opinion on the Albian-Cenomanian age of the "black flysch" in the Grajcarek Succession was expressed by Oszczypko et al. (2004). It was repeated recently by Malata and Oszczypko (2010, p. 240) who stated "...that only one Albian-Cenomanian "black flysch" complex should be distinguished in the Grajcarek thrust-sheet of the Pieniny Klippen Belt in Poland...".

Because in recent years, the main stream of discussion related to the stratigraphical position of the "black flysch" deposits has concentrated on the Grajcarek Unit of the northernmost part of the Pieniny Klippen Belt, the present authors decided to investigate the outcrops of "black flysch" deposits in the inner parts of the Pieniny Klippen Belt. Of special importance are the exposures of "black flysch" near Podubocze at Czorsztyn in Poland (Fig. 1B) described by Gedl (2008a, $b)$ and Barski et al. (2010, 2011a, b), as well as a newly discovered (Segit, 2010) exposure of "black flysch" at Kamienka in Eastern Slovakia (Fig. 1B). "Black flysch" deposits at Hałuszowa (Fig. 1B) oc- curring in the northernmost part of the Pieniny Klippen Belt and attributed to the Grajcarek Unit (Fig. 1B), which have been described recently by Gedl (2007, 2008b), were studied also for comparison. The results of investigations in both these areas supplement our general knowledge of the "black flysch" deposits as regards the stratigraphy, palaeogeography and tectonics of these deposits in the Pieniny Klippen Belt.

\section{PALYNOLOGY-MATERIAL AND METHODS}

Fourteen samples from the Podubocze I, II and III sections, three samples from the Hałuszowa section and three samples from the Kamienka section were analysed palynologically focusing on the dinoflagellate cyst assemblages (Table 1).

The rock material was processed following standard palynological preparation (Poulsen et al., 1990), including $37 \% \mathrm{HCL}, 40 \% \mathrm{HF}$. A residuum of about $50 \mathrm{~g}$ per clayey lithology and about $100 \mathrm{~g}$ per sandstones was obtained for the analysis using a 15 micrometer diameter sieve and condensed by heavy liquid $\left(2 \mathrm{~g} / \mathrm{cm}^{3}\right)$ separation.

Microphotographs were taken using a Nikon Eclipse E-600 microscope with interference-contrast equipment and a digital camera. Fluorescence observations of organic matter of selected samples were preceded with $100 \mathrm{~W}$ high pressure mercury lamp and NIKON-B2A EX 450-490, DM 505, BA 520 filter set on unoxidized palynological residues mounted in a deionized water medium.

Most of the samples yielded dinoflagellate cysts of varied preservation. The degradation of dinoflagellate cysts is caused more by mechanical processes than by thermal maturation, oxidation or biological decay.
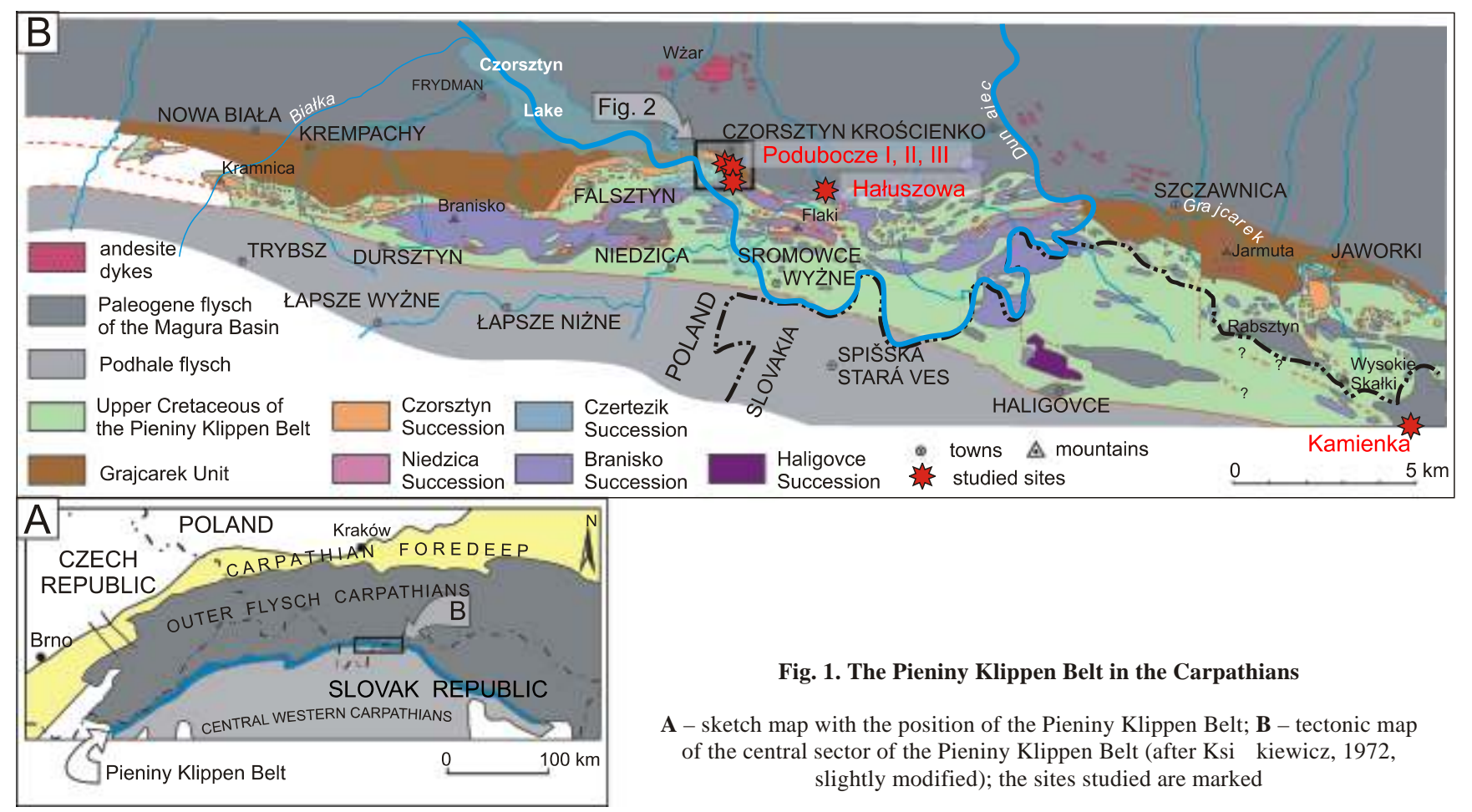

Fig. 1. The Pieniny Klippen Belt in the Carpathians

A - sketch map with the position of the Pieniny Klippen Belt; $\mathbf{B}$ - tectonic map of the central sector of the Pieniny Klippen Belt (after Ksią kiewicz, 1972, slightly modified); the sites studied are marked 
Distribution of dinoflagellate cysts in the sections studied at Podubocze, Kamienka and Hałuszowa

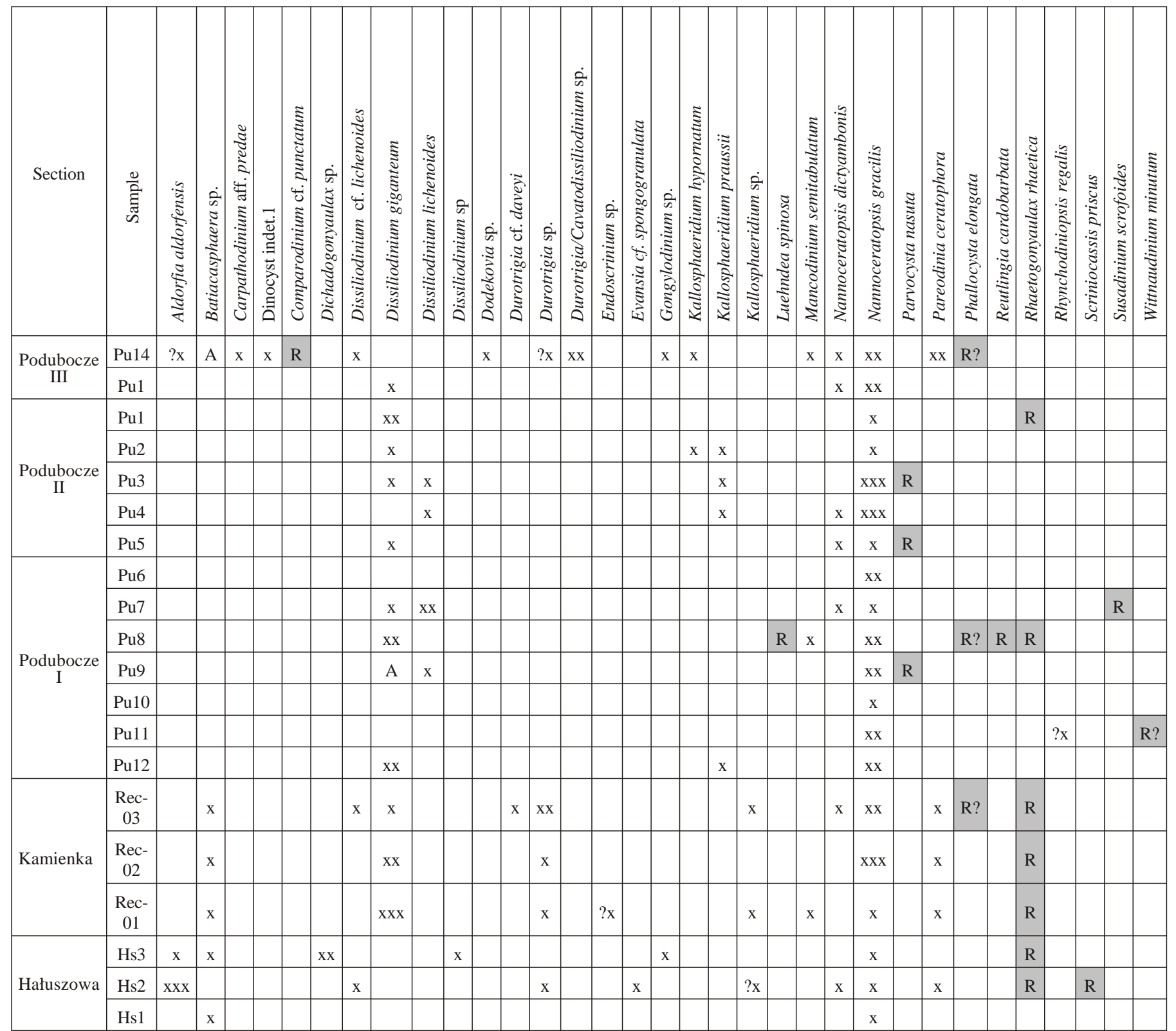

? $\mathrm{x}$ - occurrence in question, $\mathrm{x}$ - single or rare occurrence, $\mathrm{xx}$ - frequent occurrence, $\mathrm{xxx}$ - abundant occurrence, $\mathrm{A}$ - mass occurrence, $\mathrm{R}$ - recycled

The aim of our present study is biostratigraphical analysis, therefore the dinoflagellate cyst range chart (Table 1) shows qualitative and semi-quantitative data.

The stratigraphic ranges of the dinoflagellate cyst key species used in biostratigraphical analysis are based on the synthetic works of Riding and Thomas (1992), Poulsen (1998), and Poulsen and Riding (2003) as well as on selected papers (Woollam and Riding, 1983; Prauss, 1989; Feist-Burkhardt, 1990, 1994; Feist-Burkhardt and Wille, 1992; Riding and Ioannides, 1996; Stover et al., 1996; Burkhalter et al., 1997; Feist-Burkhardt and Monteil, 1997, 2001). Some new remarks on the Bajocian dinoflagellate cyst stratigraphy of the Pieniny Klippen Belt provided by Segit (2010) were also considered.

The evidence of dinoflagellate cyst redeposition mainly takes the form of co-occurrence of key taxa with discordant stratigraphical ranges but the blue light excitation method also provided good results in this respect.

Ultra-violet and blue light excitation is a technique applied to various forms of the organic matter. It can be used for polished coal samples, thin-section samples and chemically macerated palynological residues in either reflected or transmitted light. 
For coal petrologists this method is appropriate to assess the proportions of the primary liptinitic macerals versus diagenetic macerals such as exsudatinite, bitumens and hydrocarbons across the "oil window" (Radke et al., 1980). Fluorescence is also used to establish an index of the thermal maturation of organic-rich sediments (Van Gijzel, 1971). Spectral measurements of organic matter fluorescence provide a quantitative proxy of thermal maturation for standard comparisons (van Gijzel, 1971, 1981). Finally, fluorescence may help to determine the origin of palynomorphs and various types of amorphous or structureless organic matter (Tyson, 1993). Fluorescence colour of the palynomorphs is often understood as a function of maturity, but significant variation can also reflect the degree of synsedimentary or diagenetic oxidative alteration (Tyson, 1993).

Doláková and Burešová (2007) successfully applied florescence microscopy to recognize redeposited Neogene palynomorphs in Quaternary cave deposits from the Moravian karstic areas and to trace Miocene reworked components in marine deposits of the Carpathian Foredeep.

Van Gijzel (1967) first stated that with increasing geological age all exine of pollen grains and spores shows a change in fluorescence colour from the blue-green for Neogene towards the orange-red part of the spectrum for Mesozoic. He also concluded that fossil pollen grains and spores of various types of the same age show a more or less characteristic fluorescence colour.

Recently Brenner and Biebow (2001) as well as Feist-Burkhardt (2009) suggested that pigmentation ratio and low autofluorescence of fossil cysts may be an indicator of heterotrophy. Thus this feature could be used as a proxy for heterotrophic and photosynthetic dinoflagellate cyst behavior.

\section{"BLACK FLYSCH” DEPOSITS IN THE SECTIONS STUDIED: LITHOLOGY AND AGE}

\section{PODUBOCZE AT CZORSZTYN}

LITHOLOGY

The "black flysch" (Szlachtowa Fm.) deposits crop out at Czorsztyn (Podubocze sections) at the Czorsztyn Dam Lake (sections I-II along unnamed creeks, section III on the bank of the lake - Fig. 2). These deposits were attributed to the Branisko Succession (Birkenmajer, 1957a, b, 1962, 1963a, b; Gedl, 2008a, $b$ ). The area of study represents the largest outcrops of the "black flysch" deposits ascribed to the Branisko

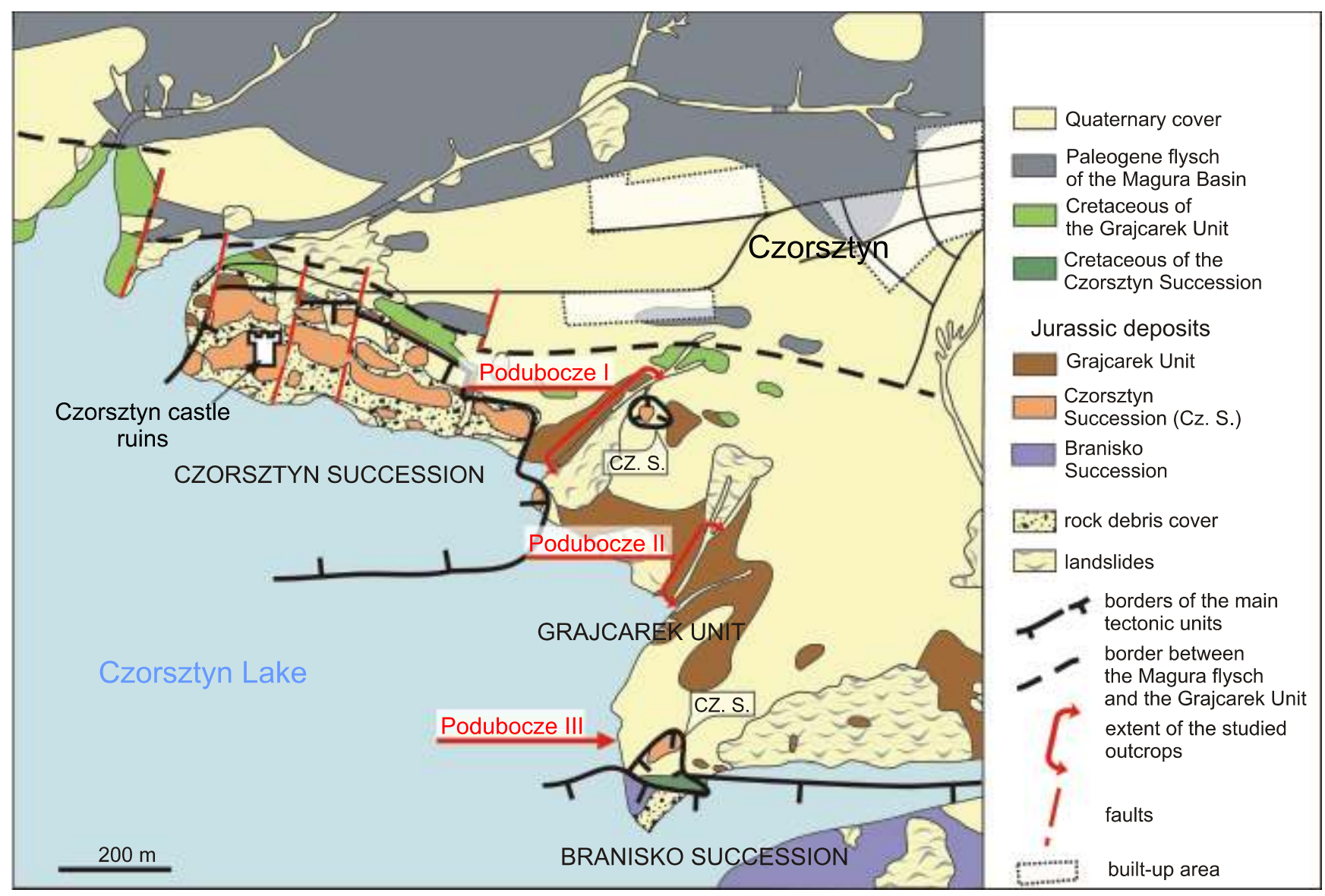

Fig. 2. Geological map of the vicinity of Czorsztyn village with the position of the Podubocze I, II and III sites (map after Birkenmajer, 1963a, 1979; modified and reinterpreted) 
Succession in Poland, which additionally yield fairly continuous and not strongly tectonised sections.

According to Birkenmajer (1957a) the deposits in question of the Branisko Succession consist of three units:

- dark gray shales with thin intercalations of sandy graded crinoidal limestone, about $10 \mathrm{~m}$ in thickness;

- gray and black strongly micaceous shales with intercalations of micaceous sandstone and siltstone: the sandstones are mostly graded and horizontally laminated - about $140 \mathrm{~m}$ in thickness;

- sandstones dominating over shales; sandstones up to $4 \mathrm{~m}$ in bed thickness, brittle, fine or medium-grained, graded, but in places massive - not bedded, with quartz grains, mica flakes and fragments of shales and plant detritus - about $50 \mathrm{~m}$ in thickness; later, Birkenmajer (1977) added to general succession of the "black flysch" deposits distinguished formally as the Szlachtowa Formation, a fourth member consisting of gray to black finely micaceous shale with thin intercalations of strongly micaceous sandstone.

The deposits studied consist of dark clays, laminated micaceous shales and sandstones occurring in different proportions, and differing in some features (such as bed thickness, structure of sandstones) in the succession. Although the beds studied are in normal (not overturned) position, and their tectonic structure in particular sections is fairly uniform, their detailed correlation is impossible. The succession can be subdivided, however, into a few major sedimentary packets.
The sections Podubocze I (N 49 $25^{\prime} 59.7^{\prime}$, , E 20 $0^{\circ} 19^{\prime} 13.4^{\prime \prime}$ ') and Podubocze II (N 49 $25^{\prime} 51.6^{\prime}$ ', E 20 $0^{\circ} 19^{\prime} 23.5^{\prime}$ ') in the creeks at Podubocze (Figs. 3 and 4) show dominant black and dark gray clays with thin intercalations of micaceous shale and sandstone (a few $\mathrm{cm}$ in thickness up to $0.25 \mathrm{~m}$ ). The deposits are often graded, usually of normal complete type, or parallel laminated - either in graded beds or independently, and often showing features of distal turbidites. Hieroglyphs (casts) are mostly of organic origin; those of inorganic character e.g., flute casts, are rare ( $c f$. Birkenmajer, 1957a). The detrital material within sandstone beds is composed of quartz grains, carbonate lithoclasts, and less commonly of fragments of shale, sandy limestone, sandstone and siliceous rock; fragments of coal are encountered, also metamorphic rocks represented by fragments of schist (quartz-feldspar-mica schists) occur. Shales include abundant mica flakes. The organic fragments are represented by crinoid ossicles and occasional well-preserved bryozoan colonies. The deposits at least $70 \mathrm{~m}$ in thickness, and show the general features of the unit 2 of the "black flysch" succession as defined by Birkenmajer (1957a).

A somewhat different lithology is observed at the entrance to the creek of Podubocze II, where a single bed of graded crinoidal limestone $(0.1 \mathrm{~m}$ thick), occurs in a succession of black clays, about $2.5 \mathrm{~m}$ in thickness: the relation of these deposits to other deposits from sections I and II at Podubocze is not clear, and the deposits are poorly exposed. Nevertheless their affinity to unit 1 of Birkenmajer (1957a) seems probable.

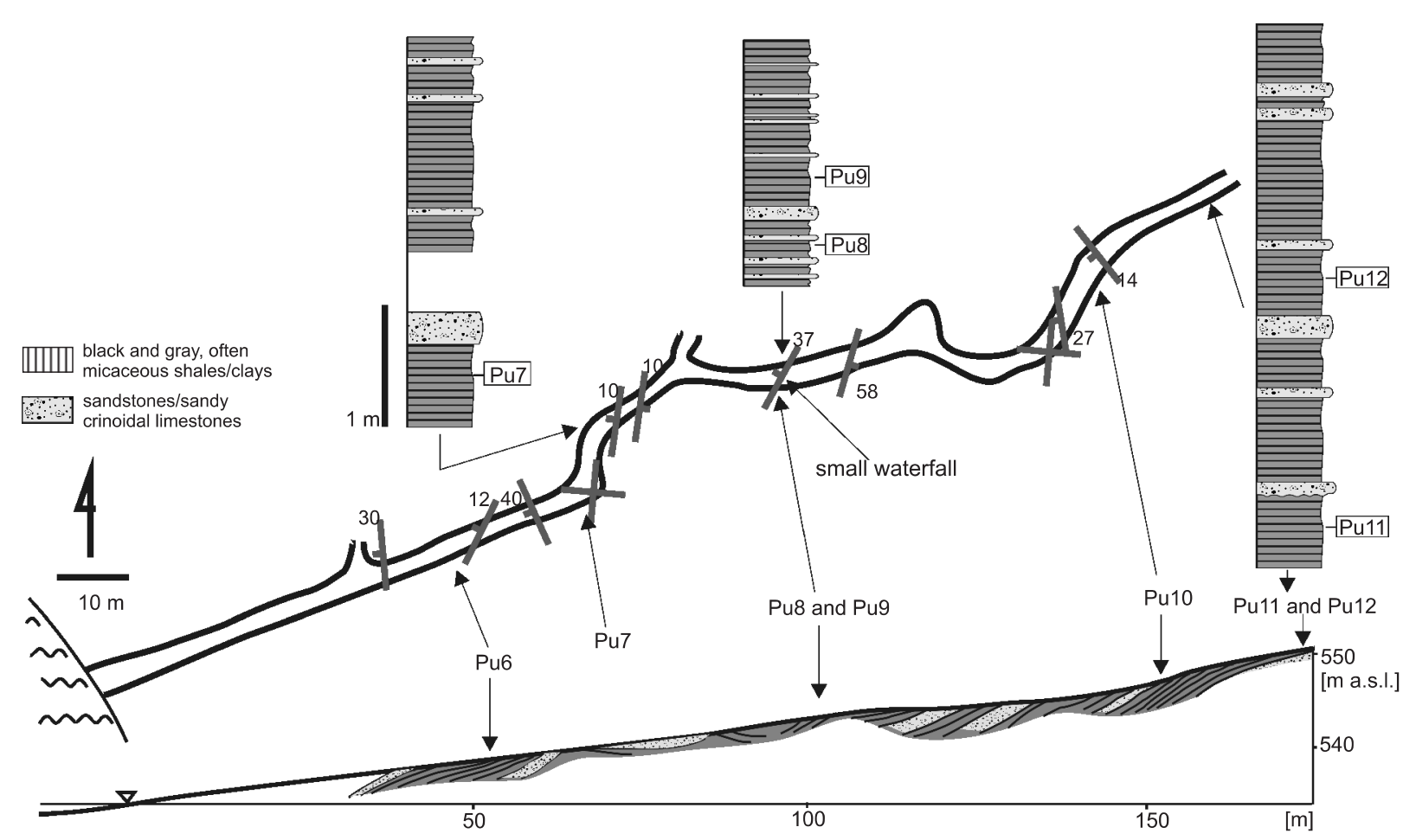

Fig. 3. Site Podubocze I: geological transect, sketch map of the ravine and exemplary lithological section of the Szlachtowa Formation 


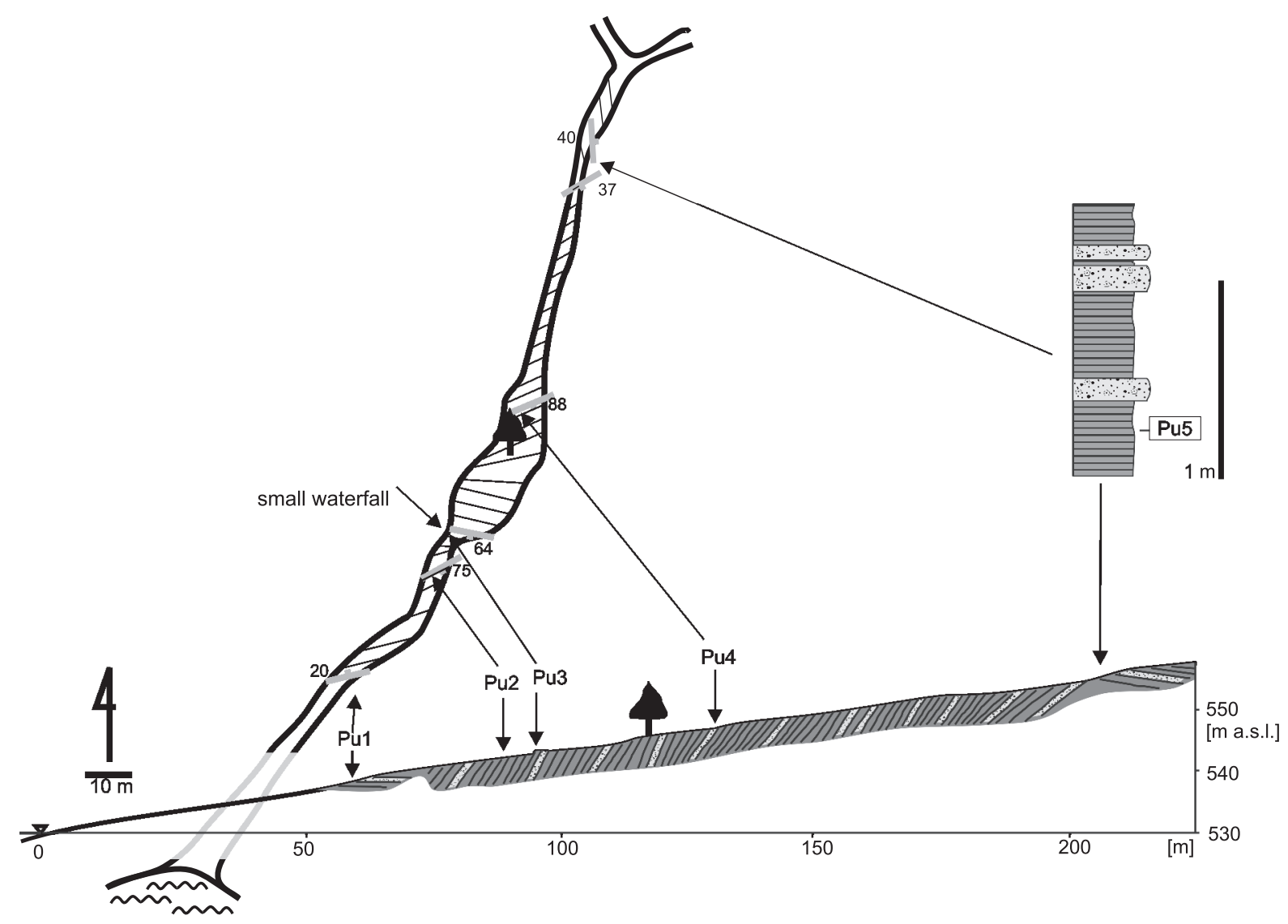

Fig. 4. Site Podubocze II: geological transect, sketch map of the ravine and exemplary lithological section of the Szlachtowa Formation

For explanations see Figure 3

The section Podubocze III (N 49²5'47.0', E 20¹9'18.7' ') on the bank of Czorsztyn Lake (Fig. 5) shows in its lower part two very massive sandstone beds inclined towards the SE, and the right way up: the lower bed seen to about $1 \mathrm{~m}$ thick (base not exposed), and an upper bed is about $1.5 \mathrm{~m}$ thick (top not exposed); at their boundary is a thin siltstone layer about $1 \mathrm{~cm}$ in thickness. The sandstones are brittle, massive, without any internal structure, composed of fine and medium grains of quartz, with abundant mica flakes, fragments of black shale and plant detritus. They are possibly fluxoturbidites. Their lithological character corresponds very closely to that of unit 3 of the "black flysch" succession of Birkenmajer (1957a).

Younger deposits appear still higher in the Podubocze III section, where after a 2-3 m unexposed interval, there appear very thin bedded sandstone layers (mostly from a few to $10 \mathrm{~cm}$ thick, but attaining up to $20-30 \mathrm{~cm}$ in thickness) in a succession of greenish clays and shales. The sandstone layers are strongly micaceous and laminated; they show the presence of organic casts (hieroglyphs) showing the beds are the right way up. The total thickness of the beds exposed is about $4 \mathrm{~m}$. The deposits show similarity to the uppermost unit 4 of the Szlachtowa Formation of Birkenmajer's (1977) subdivision.
AGE

The stratigraphical position of the deposits from the Podubocze creeks (sections I and II) was interpreted recently by Gedl $(2008 a, b)$. He analysed the dinoflagellate cysts taken from both sections and concluded that those recognized here are presumably of Late Toarcian age "composed chiefly of the genus Nannoceratopsis" as well as of Early Bajocian age with Dissiliodinium giganteum (Gedl 2008b, p. 184). The samples which indicate the Late Toarcian age were taken by Gedl (2008b, p. 52) from the Podubocze Creek section II in its upper part, at, and somewhat below, the creek bifurcation. It should be remembered, however, that the stratigraphical interpretation of Gedl (2008b) differs from that from his earlier paper (Gedl, 2008a), where the deposits of the "black flysch" (Szlachtowa Formation) from both sections have been interpreted as corresponding to the Upper Aalenian-Lower Bajocian.

The present authors analysed samples taken from clays and sandstones from all the sections studied of Podubocze. The samples from separate sections of Podubocze I, II and Podubocze III were placed in the stratigraphic sequence reflected by the sample numbers arranged in descending order. 


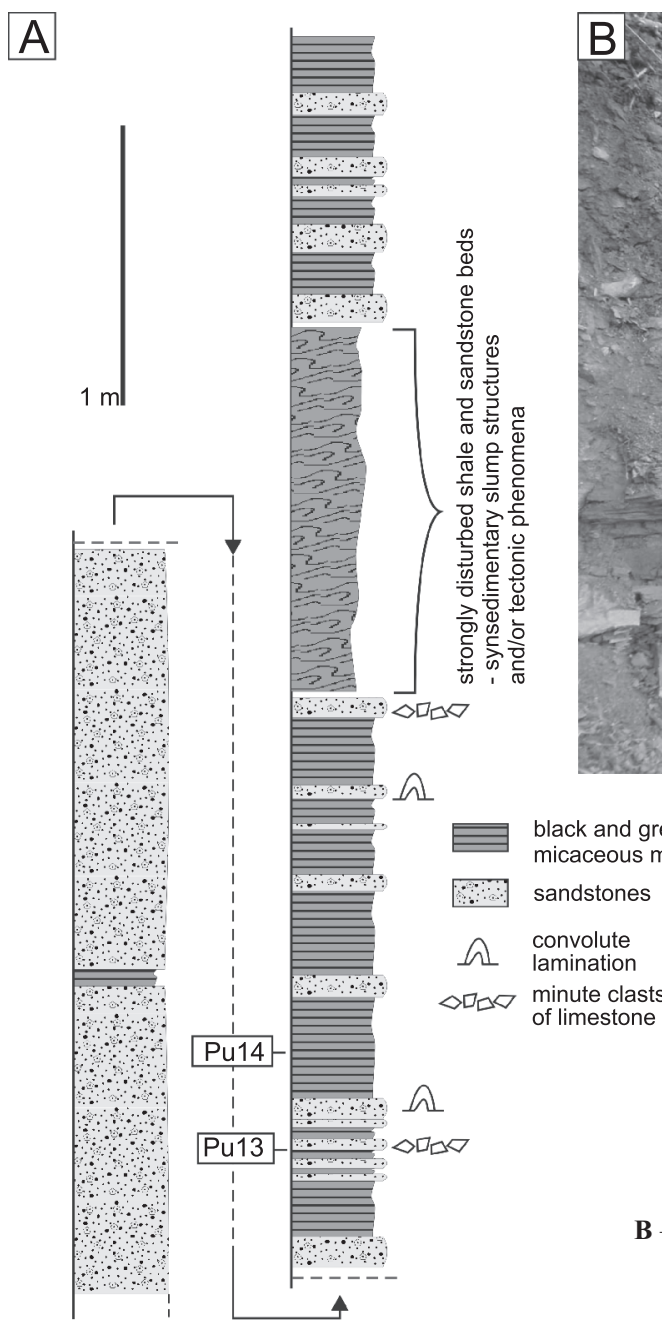

Fig. 5. Site Podubocze III

A - detailed lithological section of the Szlachtowa Formation;

B - exposure of the Szlachtowa Formation; for explanations see Figure 3

Nevertheless, due to the complicated tectonics of the area the exact stratigraphic relation between the sections is unknown.

All samples collected yielded a relatively moderate-abundance, low-diversity dinoflagellate cyst assemblage. It consists of 33 forms of dinoflagellate cyst (Table 1), where the genera Nannoceratopsis and Dissiliodinium (Fig. 6), are consistently present. The species incidentally found in the material studied such as Wittnaudinium minutum (Early Jurassic), Susadinium scrofoides (Early Jurassic), Reutlingia cardobarbata (Early Jurassic), Parvocysta nasuta (Early Jurassic; Fig. 6G), Comparodinium cf. punctatum (Early Jurassic), ?Luehndea spinosa (Early Jurassic) and Rhaetogonyaulax rhaetica (Late Triassic; Fig. 6F, H), indicate biostratigraphic redeposition.

In the present study, sample Pul1 from the Podubocze I section and samples Pu1, Pu3 and Pu4 from the Podubocze II section were examined by fluorescence microscopy by blue light excitation to distinguish the character and rank of reworking of the dinoflagellate cysts. The examination revealed two types of fluorescence which resulted in recognition of two differently preserved dinoflagellate cyst assemblages: (1) consisting of Nannoceratopsis gracilis and stratigraphically older species (e.g., Rhaetogonyaulax rhaetica, Parvocysta nasuta) con- sistently showing dark yellow (orange) fluorescence (Fig. 7); the share of this assemblage composed of reworked cysts fluctuates between 10 to $30 \%$ in the samples studied; (2) an assemblage consisting of Dissiliodinium giganteum, Dissiliodinium lichenoides and Nannoceratopsis gracilis characterized by bright yellow to green fluorescence colours (Fig. 7). As the stratigraphic ranges of Dissiliodinium spp. are restricted to uppermost Aalenian-Lower Bajocian, the second assemblage must be regarded as occurring in situ and being age-indicative of the deposits in question. The fact that Nannoceratopsis gracilis in the same sample characterizes two types of fluorescence colours is worthy of attention. This means that the same species, having a wide stratigraphical range, occurs in the samples as both in situ and recycled examples. Abnormal enrichment of assemblages in the cysts of Nannoceratopsis, partly caused by reworking, may lead to wrong stratigraphical and/or environmental interpretation of the deposits.

Stratigraphically significant taxa include: Dissiliodinium giganteum (Lower Bajocian: Discites to Sauzei = Propinquans zones), Mancodinium semitabulatum (Pliensbachian-Lower Bajocian up to Humphriesianum Zone), Dissiliodinium lichenoides (Upper Aalenian-Lower Bajocian up to 

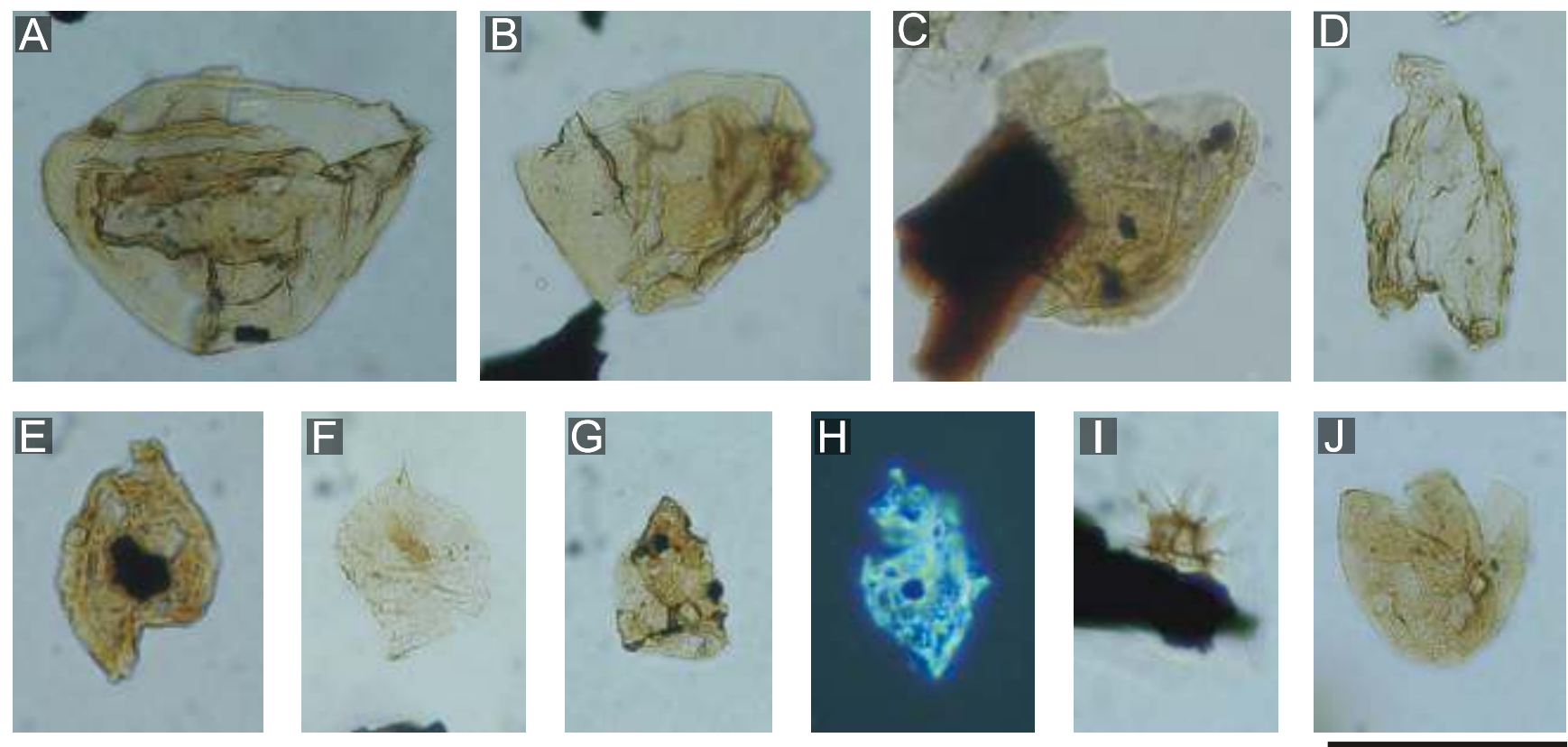

$50 \mu \mathrm{m}$ (figs. A-J)
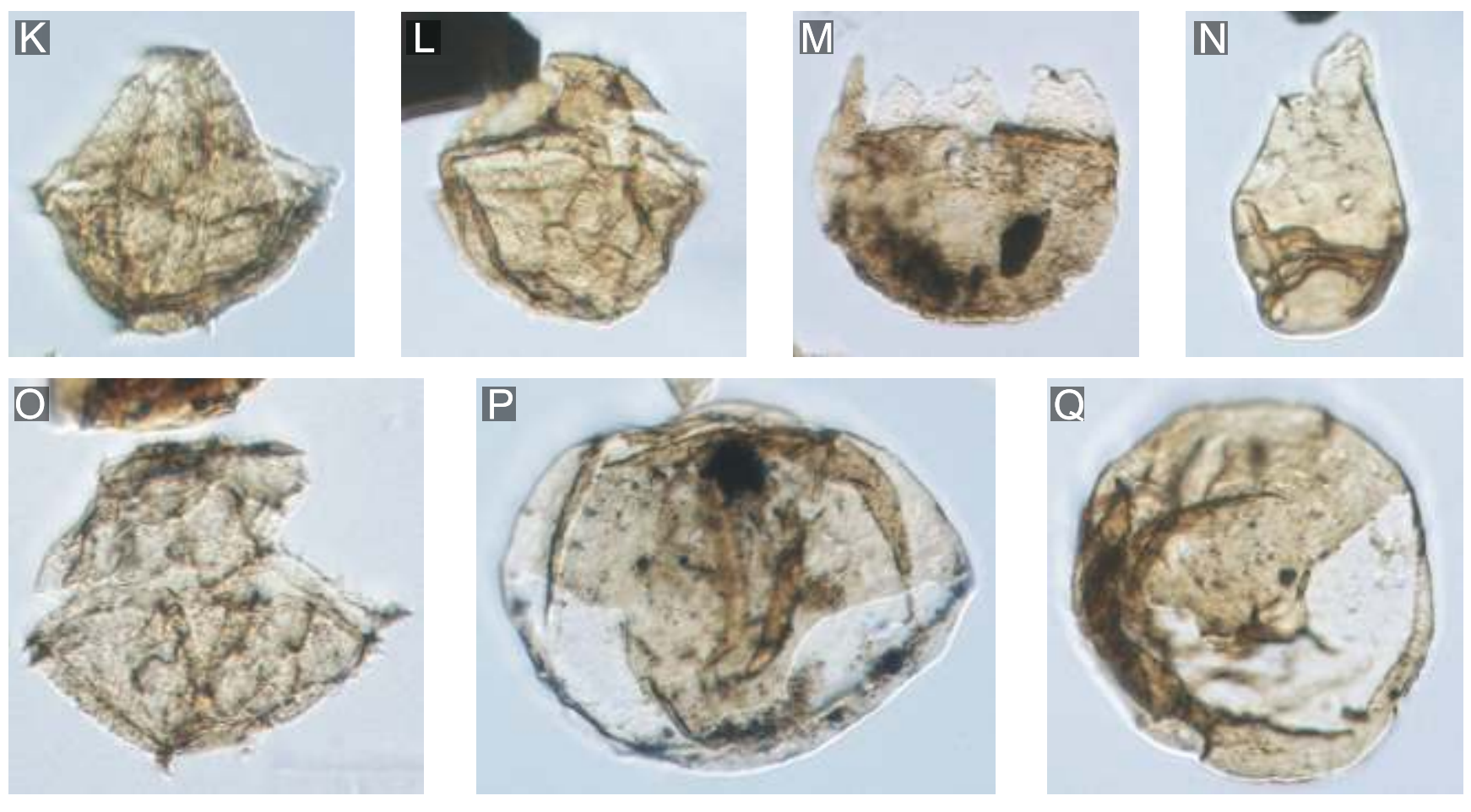

$50 \mu \mathrm{m}$ (figs. K-Q)

Fig. 6. Photographs of selected dinoflagellate cyst specimens from the samples studied - sites Podubocze I and II (Pu) and Kamienka (Rec)

A - Dissiliodinium giganteum Feist-Burkhardt, 1990 (Pu9); B - Dissiliodinium giganteum Feist-Burkhardt, 1990 (Pu1); C - Dissiliodinium lichenoides Feist-Burkhardt and Monteil, 2001 (Pu7); D - Nannoceratopsis dictyambonis Riding, 1984 (Pu4); E - Nannoceratopsis gracilis Alberti, 1961 (Pu4); F Rhaetogonyaulax rhaetica (Sarjeant, 1963) Loeblich Jr. and Loeblich III, 1968 (Pu1); G - Parvocysta nasuta Bjaerke, 1980 (Pu5); H - Rhaetogonyaulax rhaetica (Sarjeant, 1963) Loeblich Jr. and Loeblich III, 1968 (Pu8); I - ?Luehndea spinosa Morgenroth, 1970 (Pu8); J - Batiacasphaera sp. (Pu4); (A-J photo: M. Barski); K, L - Durotrigia sp. (Rec-03); M - Batiacasphaera sp. (Rec-01); N-Phallocysta elongata (Beju, 1971) Riding, 1994 (Rec-03); O Durotrigia cf. daveyi Bailey, 1987 (Rec-01); P, Q-Dissiliodinium giganteum Feist-Burkhardt, 1990, apical view, note clearly visible archeopyle type 3P (P - Rec-01, Q - Rec-02) (K-S photo: T. Segit) 

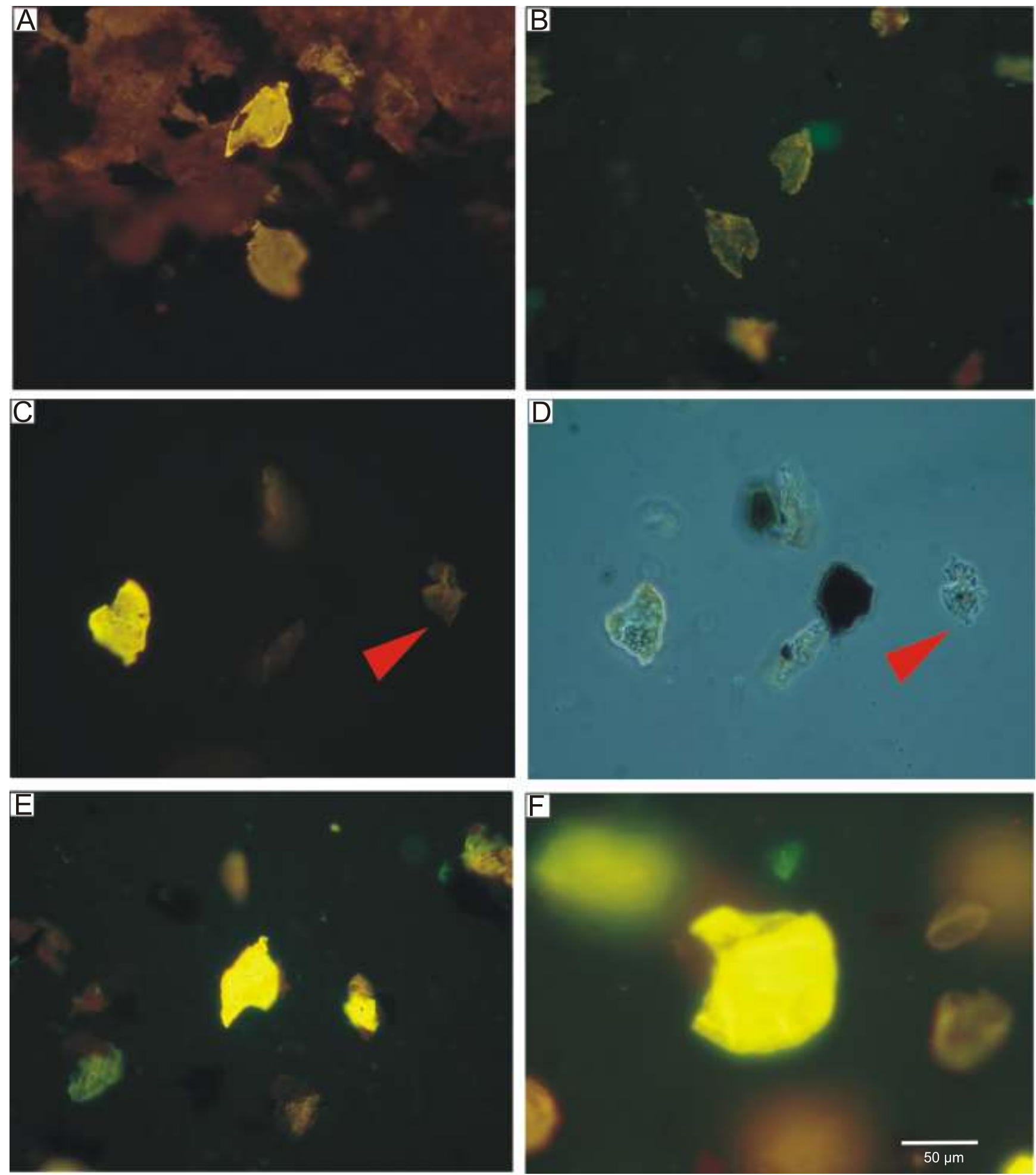

Fig. 7. Photographs of selected dinoflagellate cyst specimens examined by fluorescence microscopy - sites Podubocze I and II (Pu)

A - two specimens of Nannoceratopsis gracilis characterized by different fluorescence colours (dark yellow - recycled, bright yellow - in situ; Pu1); B two specimens of Nannoceratopsis gracilis characterized by similar fluorescence colours (Pu4); C - Nannoceratopsis gracilis and Rhaetogonyaulax rhaetica (arrowed) showing different fluorescence colours (Pu1); D - the same specimens under phase contrast; E - specimen of Nannoceratopsis gracilis demonstrating intensive bright yellow fluorescence ( $\mathrm{Pu} 4) ; \mathbf{F}$ - specimen of Dissiliodinium giganteum characterized by intensive bright yellow fluorescence (Pu4) (photo: M. Barski); scale bar is $50 \mu \mathrm{m}$ for all pictures 

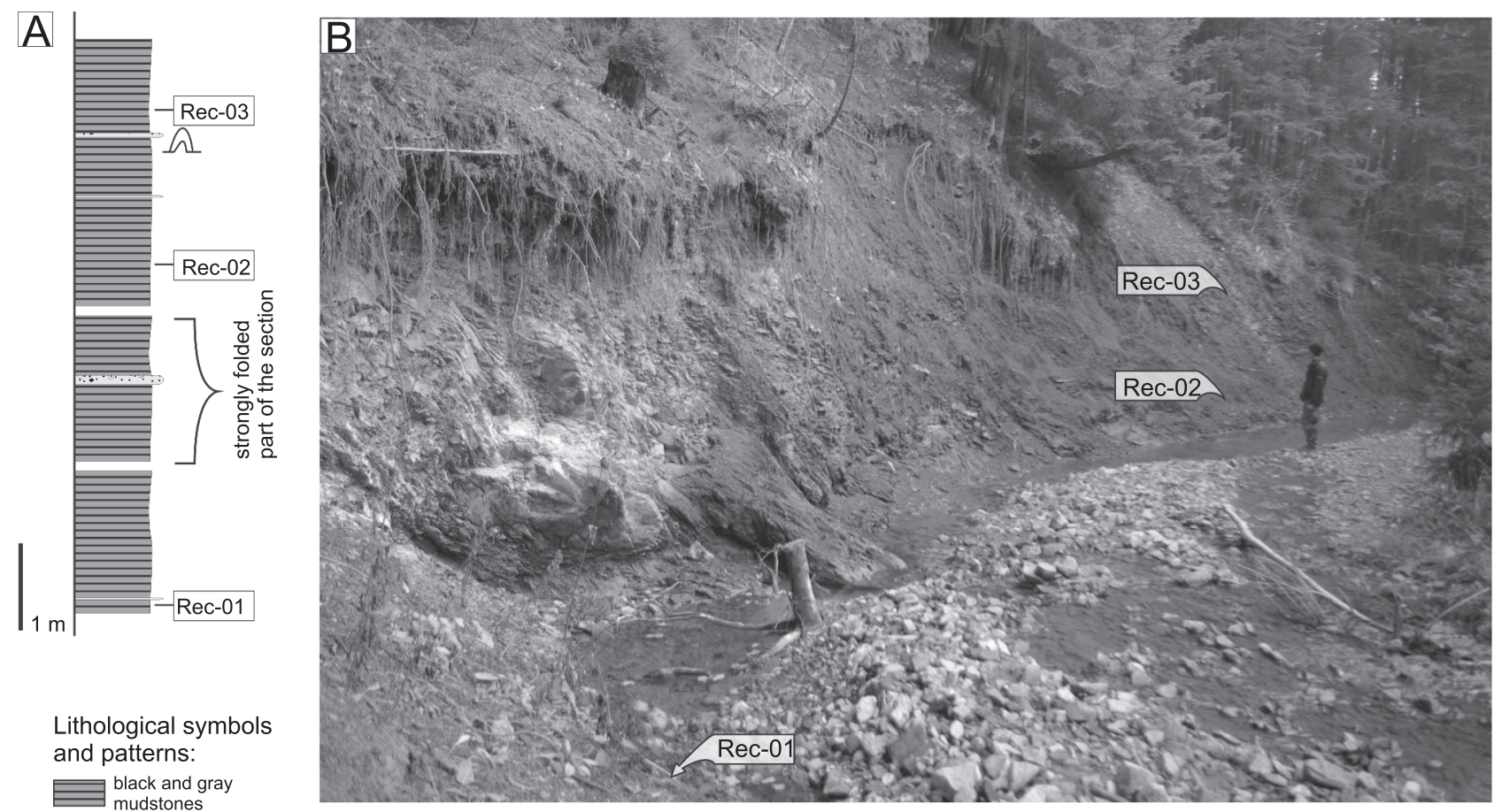

Lithological symbols and patterns:

$\begin{aligned} & \text { black and gray } \\ & \text { mudstones }\end{aligned}$
sandy crinoidal
limestones or sandstones with crinoid ossicles

A. - convolute
Fig. 8. Site Kamienka

A - the lower part of the section with the sample locations;

B - exposure of the Szlachtowa Formation on the left Riečka Stream
Laeviuscula Zone) and Nannoceratopsis dictyambonis (Upper Toarcian-Lower Bajocian up to Laeviuscula Zone), the last two species may have slightly longer ranges in the Pieniny Basin (up to Propinquans Zone, see Segit, 2010). Thus, the Podubocze I and Podubocze II sections can be assigned to the Lower Bajocian and represent the ?Discites, Laeviuscula and/or Propinquans zones. Considering the occurrence of Dissiliodinium giganteum (locally abundant), Dissiliodinium lichenoides and an absence of Durotrigia daveyi (relatively common in the Propinquans Zone of Western Slovakia according to Segit, 2010), the samples studied likely lie within the Laeviuscula Zone. Due to an absence of stratigraphically valuable species in sample Pu6 from Podubocze I, including the species Nannoceratopsis gracilis having a wide stratigraphical range, its stratigraphic position cannot be precisely recognized; this sample was taken from the uppermost beds of the section and therefore is not older than the Laeviuscula Zone.

The dinoflagellate cyst assemblage from Podubocze III has been studied in two samples taken in close proximity: Pu13 and Pu14. Sample Pu13 corresponds to the Lower Bajocian Discites to Propinquans Zone interval accordingly to the presence of rare specimens of Dissiliodinium giganteum. Sample Pu14 contains, besides less informative species, two forms referred to as Dissiliodinium cf. lichenoides (Discites?Propinquans zones) and Carpathodinium aff. predae. The range of Carpathodinium predae, being closely related to Carpathodinium aff. predae, is from the Garantiana Zone of the Upper Bajocian up to the Middle Bathonian Progracilis Zone. This contradiction in stratigraphical ranges of the two taxa precludes unequivocal stratigraphical interpretation of the sample in question. Attribution of the sample to the Lower Bajocian seems more probable, however, according to data of Riding and Thomas (1992) who postulated the appearance of the genus Carpathodinium in the Discites-Humphriesianum Zone interval.

\section{KAMIENKA}

\section{LITHOLOGY}

This site (N 49 21'29.4', E 20'36'21.1'") is located on the southern slope of the Małe Pieniny range, by the villages of Kamienka and Litmanová, Eastern Slovakia.

A bare escarpment developed on the left bank of the Riečka Stream and a discontinuous section exposed over a distance of ca. $100 \mathrm{~m}$ along the stream bed, expose massive dark gray mudstones and shales with rare thin fine-grained sandstone beds and a few, up to $10 \mathrm{~cm}$ thick, graded sandy crinoidal limestone layers, locally showing convolute lamination (Fig. 8). These deposits, though corresponding to the Szlachtowa Formation sensu lato, show distinctive features, i.e. a very low proportion of sandstone layers and a small content of detrital mica; only in the uppermost few metres of the section do slightly micaceous sandstone intercalations become relatively frequent. The sequence has an exposed thickness of some $65 \mathrm{~m}$ (the base and top are not seen) and apart from its lower, strongly tectonised part, the strata generally dip to the south at about $40^{\circ}$ (strike values are around $95-110^{\circ}$ ) and rest in normal position. 
A large klippe, at the foot of which the section investigated is located, represents the Maiolica-type limestone of the ?Branisko Succession, but a section exposed close to the north of the site in the quarry represents the Niedzica Succession (Segit, 2010). Deposits of the Szlachtowa Formation at Kamienka, located in the topographical low in the inner zone of the Klippen Belt, probably occupies the lowermost tectonic position within the Pieniny Klippen Belt structure of the area (cf. Plašienka and Mikuš, 2010).

$$
\text { AGE }
$$

Three samples of dark mudstone were taken from the lower, best exposed part of their section, and analysed for the dinoflagellate cyst content. Sample Rec-01, which represents the basal, disturbed sequence of black clays, yielded a well-preserved assemblage, largely dominated by Dissiliodinium giganteum (Fig. 6P). D. cf. lichenoides and some other undetermined representatives of the genus Dissiliodinium (Fig. 9), as well as Nannoceratopsis gracilis, Batiacasphaera sp., Kallosphaeridium sp., Durotrigia sp., Pareodinia ceratophora, Mancodinium semitabulatum and Rhaetogonyaulax rhaetica (Fig. 10) were also found. Samples Rec-02 and Rec-03, obtained from slightly younger beds in the continuous succession, revealed dinoflagellate cyst assemblages slightly different than that of sample Rec-01, but similar to each other: Nannoceratopsis gracilis is the most prevalent taxon in both samples, Dissiliodinium sp., D. giganteum, D. cf. lichenoides and Durotrigia sp. (including D. cf. daveyi) are relatively frequent and occur in variable proportions. Sample Rec-03 yielded also rare Nannoceratopsis dictyambonis, a single, damaged specimen of Phallocysta elongata, and a dinoflagellate cyst questionably attributed to ?Endoscrinium sp.

The deposits of the section studied are assigned to the Lower Bajocian, presumably the Laeviuscula and/or Propinquans Zone, as based chiefly on the stratigraphical range of Dissiliodinium giganteum (Discites-Propinquans zones; see Feist-Burkhardt and Monteil, 2001) and Durotrigia cf. daveyi (Laeviuscula/Propinquans-Humphriesianum zones of the Lower Bajocian, see Burkhalter et al., 1997; up to the Upper Bajocian; see Feist-Burkhardt and Monteil, 1997). Indeed, according to the remarks by Feist-Burkhardt and Wille (1992), the acme of typical D. giganteum, as found in sample Rec-01, indicates the Laeviuscula or Propinquans zones, rather than the Discites Zone. It should be remembered that although the last occurrence of Dissiliodinium lichenoides was previously reported from the Laeviuscula Zone only (see Feist-Burkhardt and Monteil, 2001), specimens closely related to this species have been found in the Propinquans Zone of the Pieniny Klippen Belt in Western Slovakia (Segit, 2010). The taxa known from the Pliensbachian or Toarcian up to the Lower Bajocian are: Mancodinium semitabulatum, Nannoceratopsis dictyambonis and Phallocysta elongata, but the two latter species, often considered to be extinct by the Laeviuscula Zone (see Feist-Burkhardt, 1990; Burkhalter et al., 1997) or the Propinquans Zone (Riding and Thomas, 1992), are rare and poorly preserved in the section studied and may be reworked (certainly in the case of Rhaetogonyaulax rhaetica). The prevalence of Nannoceratopsis gracilis in samples Rec-02 and Rec-03 may also be related with palynomorph resedimentation and concentration in turbidity current flow, though a primary (i.e. ecological) factor cannot be excluded.

\section{HAŁUSZOWA}

LITHOLOGY

Some dark deposits exposed in a gully at Hałuszowa, with no precise location given, were originally regarded as of Cretaceous age (Blaicher and Sikora, 1969). Gedl (2007) recognized, in a left tributary of the Hałuszowski Stream, both Cretaceous and Middle Jurassic strata attributed by him to the Hałuszowa Formation and the Szlachtowa Formation, respectively. We have investigated the upper part of this strongly tectonised section (N 49 $25^{\circ} 45.4^{\prime \prime}$, , E $20^{\circ} 21^{\prime} 25.0^{\prime \prime}$ ') in order to study the Grajcarek Succession and most of all its lowermost "black flysch" member (Fig. 7).

The Szlachtowa Fm. (ca. $11 \mathrm{~m})$, is here represented by a continuous sequence of dark gray, shales and mudstones slightly micaceous in some horizons, are rarely intercalated with thin sandstone beds (usually a few, but up to $30 \mathrm{~cm}$ thick) with graded bedding showing abundant crinoid fragments and less commonly small quartz grains and carbonate lithoclasts.

AGE

Three samples of shale have been collected from exposures of the Szlachtowa Fm. The organic matter shows a moderate state of preservation, palynomorphs are flattened, relatively dark in colour, but still translucent. Sample Hs1 from the lower part of the section yielded poorly preserved palynological material with a few determinable dinoflagellate cysts (Batiacasphaera sp. and Dissiliodinium sp.). Sample Hs2 contains a moderately rich dinoflagellate cyst assemblage composed predominantly of Aldorfia aldorfensis, there were also a few or very few representatives of Batiacasphaera sp., Pareodinia ceratophora, Nannoceratopsis dictyambonis, $N$. gracilis, ?Dissiliodinium sp., Scriniocassis priscus, Rhaetogonyaulax rhaetica and Evansia cf. spongogranulata. The dinoflagellate cysts recovered from sample Hs3 are less abundant and their assemblage differs from that listed above. The most common species is Dichadogonyaulax cf. sellwoodii while other species, i.e. N. gracilis, Batiacasphaera sp., Aldorfia sp., Dissiliodinium sp., Kallosphaeridium sp. (Fig. 10A, B) and Rhaetogonyaulax sp. make up a minor contribution.

The stratigraphical position of sample Hs 2 cannot be lower than the Humphriesianum Zone of the Lower Bajocian, where Feist-Burkhardt and Wille (1992) drew the range base of Aldorfia aldorfensis. Although the range top of some cysts falls in the uppermost Bathonian (A. aldorfensis, N. gracilis; see Riding and Thomas, 1992), the absence of forms found in younger strata of the Szlachtowa Formation elsewhere by Gedl (2008b), i.a. Dichadogonyaulax sp., Ctenidodinium spp., 

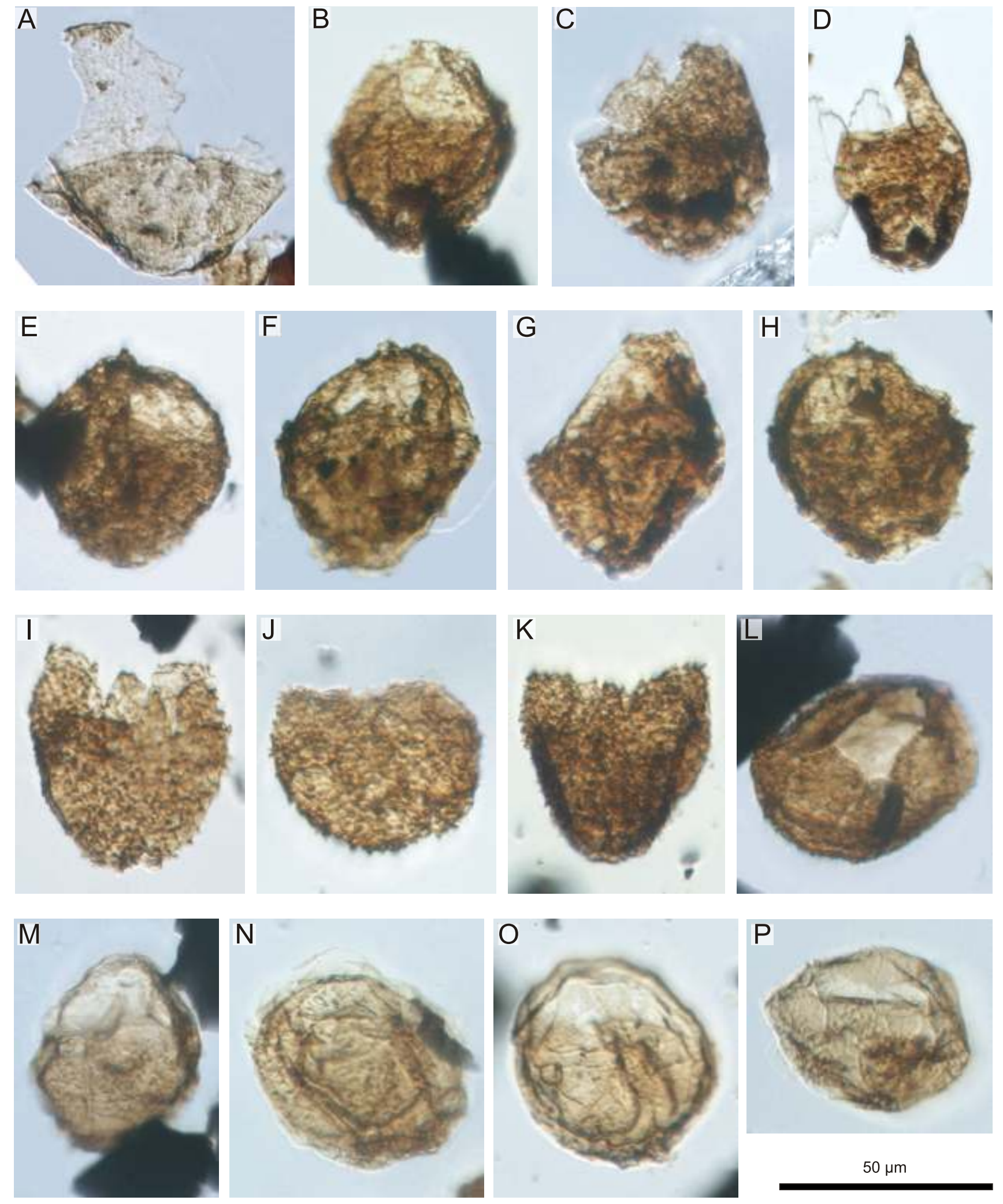

Fig. 9. Photographs of selected dinoflagellate cyst specimens from the samples studied - sites Kamienka (Rec), Podubocze II (Pu) and Hałuszowa (Hs)

A - Dissiliodinium sp. (Rec-01); B, C, E-H - Aldorfia aldorfensis (Gocht, 1970) Stover and Evitt, 1978 (Hs2), D - Pareodinia ceratophora Deflandre, 1947 (Hs2), damaged specimen, more than 2 precingular paraplates lost; I-L - Batiacasphaera sp. (Pu14); M-P - Durotrigia/Cavatodissiliodinium sp. (Pu14); cavate Gonyaulacacean cysts with 2P or 3P-type archeopyle, closely related to the genus Cavatodissiliodinium of Feist-Burkhardt and Monteil, 2001, but paratabulation expressed by fine ridges is typical of Durotrigia sp. (photo: T. Segit); scale bar is $50 \mu \mathrm{m}$ for all pictures 

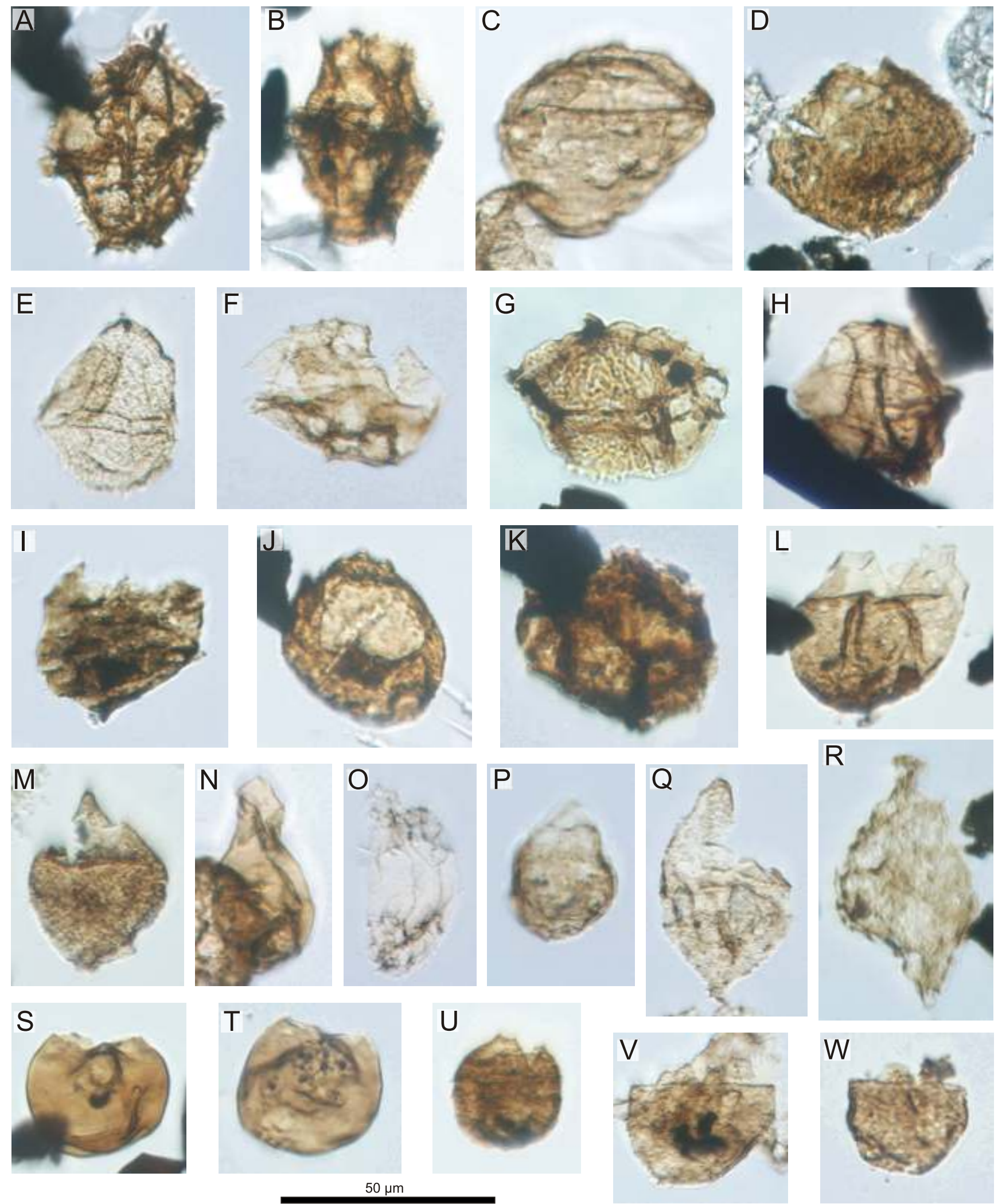

Fig. 10. Photographs of selected dinoflagellate cyst specimens from the samples studied - sites Kamienka (Rec), Podubocze III (Pu) and Hałuszowa (Hs)

A, B - Dichadogonyaulax sp. (Hs3); shrunken specimens; paracingular crests are developed symmetrically; C, J - Gongylodinium sp. (C - Hs3, J Pu14), D - cf. Aldorfia aldorfensis (Gocht, 1970) Stover and Evitt, 1978 (Pu14); E - Carpathodinium aff. predae (Beju, 1971) Drugg, 1978 (Pu14), note scabrate ornamentation (= Carpathodinium cf. predae by Gedl, 2008b); F- H - Durotrigia sp. (Hs2); I, Q - Rhaetogonyaulax rhaetica (Sarjeant, 1963) Loeblich Jr. and Loeblich III, 1968 (I - Hs3, Q - Rec-01); K - cf. Scriniocassis priscus (Gocht, 1979) Below, 1990 (Hs2); L - Kallosphaeridium hypornatum Prauss, 1989 (Pu14); M - Pareodinia ceratophora Deflandre, 1947 (Pu14), the third intercalary plate seems to be partially detached as a result of damage and bent toward the hypocyst; $\mathbf{N}$ - Phallocysta elongata (Beju, 1971) Riding, 1994 (Pu14); O - Comparodinium punctatum Wille and Gocht, 1979 (Pu14); P - Dodekovia sp. (sample Pu14); R - Nannoceratopsis dictyambonis Riding, 1984 (Pu14); S, T - Dinocyst indet. 1 (Pu14), type of archeopyle uncertain; U - Evansia cf. spongogranulata Below, 1990 (Hs2); V, W - Mancodinium semitabulatum Morgenroth, 1970 (V - Rec-01, W Pu14) (photo: T. Segit); scale bar is $50 \mu \mathrm{m}$ for all pictures 


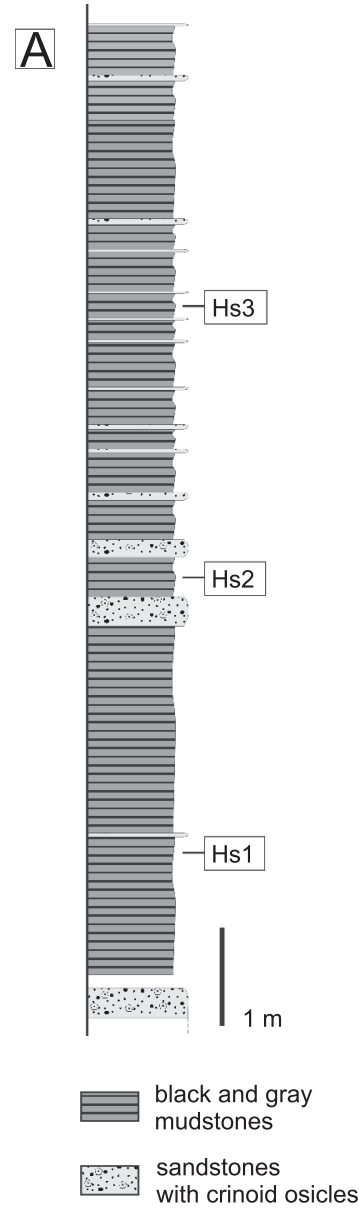

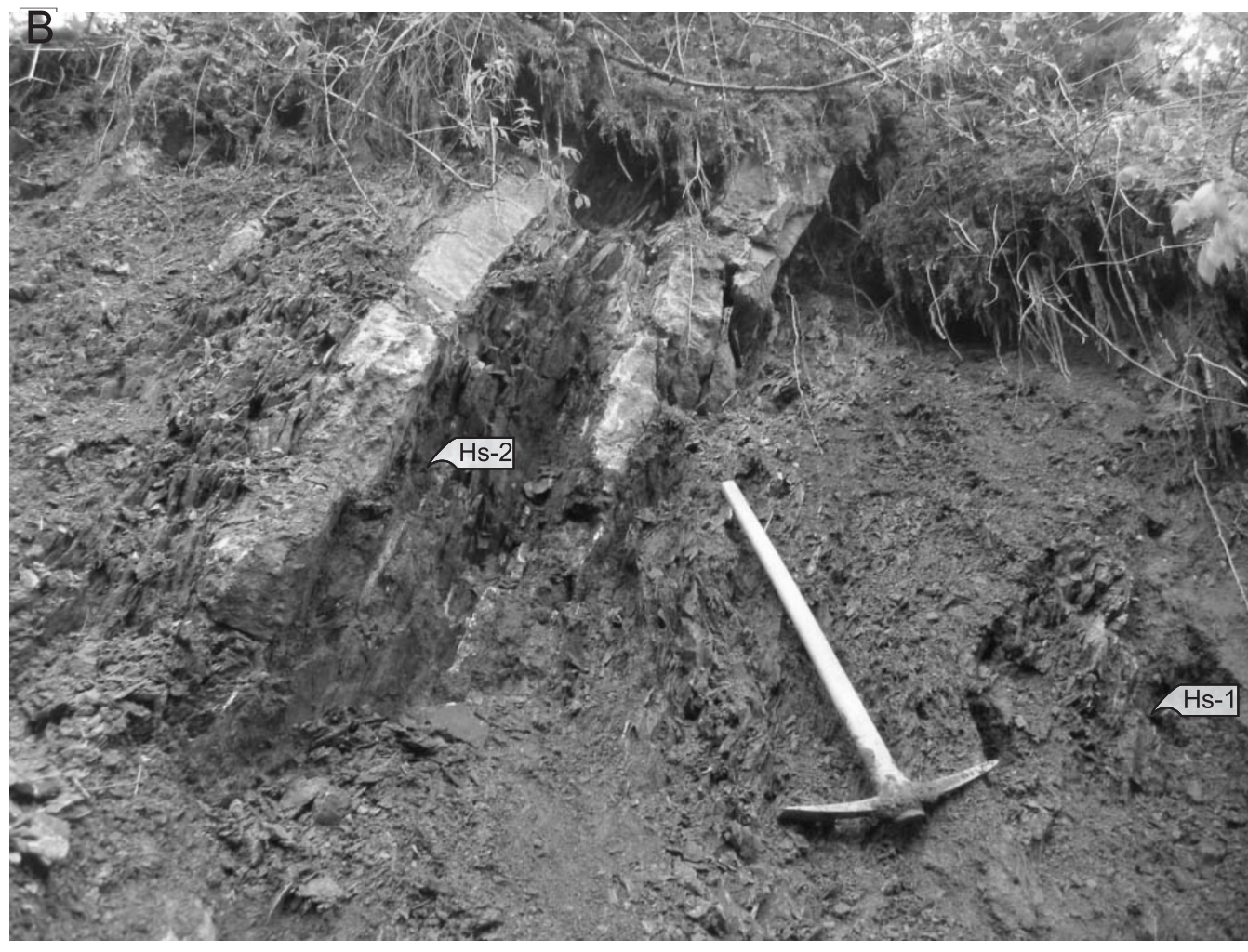

Fig. 11. Site Hałuszowa

A - detailed lithological section of the Szlachtowa Formation; B - exposure of the Szlachtowa Formation on the left side of the ravine; locations of the samples (Hs) are indicated
Meiourogonyaulax sp. or Carpathodinium predae, suggests, however, that latest Early Bajocian is the age of the sample investigated at Hałuszowa; $S$. priscus, $R$. rhaetica and probably $N$. dictyambonis are reworked palynomorphs and their state of preservation is poor. A stratigraphically important dinoflagellate cyst in sample Hs3 is Dichadogonyaulax cf. sellwoodii with a range base within the Garantiana Zone of the Upper Bajocian (Riding and Thomas, 1992; Feist-Burkhardt and Wille, 1992); there is uncertainty in its identification, however. Other species found here are: Batiacasphaera sp., Dissiliodinium sp., Nannoceratopsis gracilis, Kallosphaeridium sp. (including K. hypornatum) and Rhaetogonyaulax sp. The sample may be attributed to the Garantiana Zone of the Upper Bajocian providing that Nannoceratopsis gracilis is not reworked and co-occurs with true Dichadogonyaulax sellwoodii.

The data presented indicate that the "black flysch" deposits of the Szlachtowa Formation are generally of Bajocian age in the section studied: from the ?Discites Zone or more probably Laeviuscula Zone, representing the lower part of the Lower Bajocian, in the Podubocze sections; through the Laeviuscula and/or Propinquans zones of the upper part of the Lower Bajocian in the Kamienka section; and up to the uppermost Lower and the lower part of the Upper Bajocian in the Hałuszowa section (see also Gedl, 2008b).

\section{POSITION OF THE “BLACK FLYSCH” DEPOSITS IN THE GEOLOGICAL STRUCTURE OF THE PIENINY KLIPPEN BELT}

The deposits of the "black flysch" (= Flysch Aalenian = Szlachtowa Fm.) at Podubocze have been attributed to the Branisko Succession by Birkenmajer (1962, fig. 3; 1963a, b, pl. 8: 3).This interpretation was based on the premise that the "black flysch" deposits are stratigraphically succeeded by the Krempachy Marl Formation of Toarcian/Aalenian age (Birkenmajer, 1977; Birkenmajer et al., 2008), although the lower boundary of the latter with the Szlachtowa Formation. has been treated as "everywhere tectonic" (cf. Birkenmajer, 1977, p. 38). However, the attribution of the deposits of the Krempachy Marl Formation outcropping at Podubocze to the Branisko Succession seems improbable in the light of new data, because:

- they are older than the "black flysch" deposits below;

- they rest, moreover, "most likely overturned as is indicated by trace-fossil structures" (see Tyszka, 1995, p. 16), as opposed to the "black flysch" deposits, which as was shown above, rest in normal position.

It may be concluded that the two lithostratigraphic units, being clearly in tectonic contact belong to different successions - with the Krempachy Marl Formation representing the 
Czorsztyn Unit as do all the deposits that crop out west of the Podubocze area. This accords with the occurrence of an isolated small fragment of the Czorsztyn Succession (crinoidal limestones and ammonitico rosso deposits) in tectonic contact over the "black flysch" deposits in the area of study ( $c f$. Birkenmajer, 1962, fig. 3; 1963a, 1963b, pl. 8: 3; 2001, fig. 49). Towards the south, along the Harcygrund Valley, the "black flysch" deposits attributed to the Branisko Succession, tectonically are in contact with typical deposits of the Branisko Succession (Harcygrund Shale Fm. and Podzamcze Limestone Fm.) in a narrow zone where the Cretaceous deposits of the Czorsztyn Succession also occur (Birkenmajer, 1963a): this zone is interpreted by Birkenmajer (2001) as a tectonic window structure where the Czorsztyn Unit appears. The zone of occurrence of the Czorsztyn Succession deposits is developed along the contact of two different rock units: "black flysch" (Szlachtowa Fm.) from the north, and typical deposits of the Branisko Succession from the south.

All these data indicate that the "black flysch" (Szlachtowa Fm.) deposits which crop out in the area at Podubocze do not belong to the Branisko Succession: their contact with the Czorsztyn Succession deposits is everywhere of tectonic character, and the Czorsztyn Succession deposits are not resting below but are thrust over the "black flysch". The "black flysch" deposits belong thus to the tectonic unit underlying the Czorsztyn Unit (Fig. 2). Such an interpretation in relation to the tectonic position of the "black flysch" in the Pieniny Klippen Belt (e.g., in the Czorsztyn area) was already postulated by Horwitz (1963, p. 31) who stated that "...the Czorsztyn Unit lays on the Dogger Flysch". On the other hand, from the stratigraphical and sedimentological point of view the "black flysch" deposits as attributed now to the Lower Bajocian, cannot be placed within the Branisko Succession: this stratigraphical interval is occupied already in that succession by quite different deposits - the Harcygrund Shale Formation and the Podzamcze Limestone Formation - which do not show any sedimentological relation with the deposits of the "black flysch" studied (e.g., Wierzbowski et al., 2004).

The "black flysch" deposits studied at Podubocze are similar in lithological character and partly in stratigraphical position to those of the Grajcarek Succession in the eastern part of the Pieniny Klippen Belt in Poland (e.g., Birkenmajer et al., 2008; Gedl, 2008a, $b$ ); it should be remembered also that deposits of the Grajcarek Unit are also distinguished in the northern part of the Pieniny Klippen Belt at Czorsztyn in the area of study (Birkenmajer, 2001, fig. 49; Gedl, 2008a, b). The total thickness of the "black flysch" deposits in the Podubocze area is at least 80 metres (as calculated from the sections studied, but it is possibly much larger), similar to the estimate of Birkenmajer (1977) for the Grajcarek Succession (220 m), but markedly different to that proposed for the Branisko-Czertezik-Niedzica successions (5-30 m), although the latter calculation was based on less continuous, strongly tectonised sections.

Therefore, the "black flysch" deposits which crop out at Podubocze can be assigned to the Grajcarek Succession. This markedly changes the current tectonic interpretation of the area of study and implies the presences of a large tectonic window where deposits of Grajcarek Succession appear below the overthrusted deposits of the Czorsztyn Unit (see e.g., Horwitz, 1963; Sikora, 1971; see also Jurewicz, 1997). This new tectonic interpretation of the "black flysch" deposits in the Pieniny Klippen Belt is consistent with the results of recent studies in the eastern part of the Pieniny Klippen Belt in Poland and Eastern Slovakia by Oszczypko et al. (2010) and Plašienka and Mikuš (2010). According to these authors the Pieniny Nappe or Unit (including the Pieniny and Branisko/Kysuca successions) and the sub-Pieniny Nappe (including the Czertezik, the Niedzica and the Czorsztyn successions) are overthrust on the Faklovka or Šariš Unit composed of Upper Jurassic to Upper Cretaceous-Paleogene pelagic and hemipelagic deposits representing the lowermost structural unit of the Pieniny Klippen Belt. The deposits of the Faklovka or Šariš Unit according to Oszczypko et al. (2010) and Plašienka and Mikuš (2010) correspond mostly to those of the Grajcarek Unit or the Hulina Unit of the Polish section of the Pieniny Klippen Belt; introduction of the new name for the unit by these authors resulted from its revised tectonic interpretation. Jurassic deposits of the "black flysch" facies have not been unequivocally recognized by Plašienka and Mikuš (2010) in the Šariš Unit, because these authors suggested the "black flysch" deposits correspond rather to the Cretaceous. However, deposits of the Szlachtowa Fm. in the Kamienka section (herein), may be treated as representative of the Jurassic "black flysch" deposits in Eastern Slovakia.

\section{PALAEOGEOGRAPHICAL INTERPRETATION AND ORIGIN OF THE "BLACK FLYSCH” DEPOSITS}

The "black flysch" deposits are derived from erosion of an elevated ridge structure composed of crystalline substrate, and from Upper Carboniferous to Triassic and Lower Jurassic (Birkenmajer and Turnau, 1962; Krawczyk and Słomka, 1986, 1987; Krawczyk et al., 1987; also other papers cited therein), as well as lowermost Middle Jurassic cover. The character of the clasts indicates that they come from crystalline metamorphic substrate (metamorphic schists/gneisses), and its cover (coal and sandstones - Carboniferous; volcanic rocks, sandstones Permian; carbonates and sandstones - Triassic and Lower Jurassic), see also Birkenmajer (2007, pp. 9-12); but no fragments of deposits of Middle Jurassic (Bajocian-Callovian) to Lower Cretaceous rocks were encountered (these are easy to determinate due to their characteristic microfacies and microfossils - see e.g., Wierzbowski et al., 1999).

Interpretation of the ridge as the source area of the "black flysch" deposits, and of its position within the Carpathian basins have changed markedly in successive investigations. Originally Birkenmajer (1957a) and Birkenmajer and Turnau (1962), postulated the existence of a "Central Cordillera" placed between the area of sedimentation of the Branisko Succession, and the Niedzica Succession in the Pieniny Klippen Basin which was a source area of "black flysch" deposits. In later interpretations (Birkenmajer, 1977) the source area of the flysch deposits was the "northern eugeosynclinal ridge" (Czorsztyn Ridge). According to Sikora (1962) "...presumably part of sediments now assigned to Flysch Aalenian might prove to be Magura Lower Cretaceous beds...", and this indicated according to him the exis- 

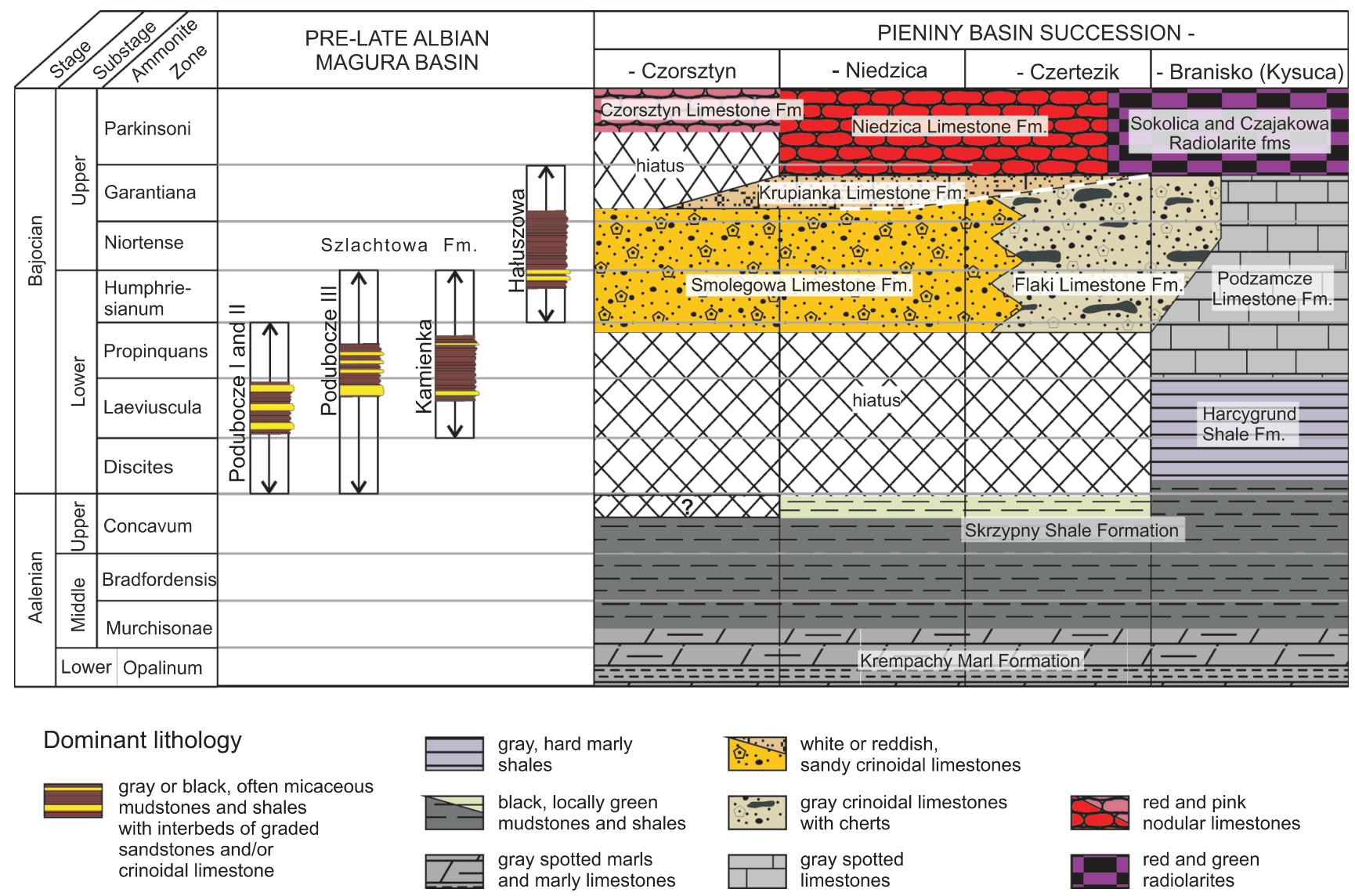

Fig. 12. Stratigraphical position of the Szlachtowa Formation in the sections studied and lithostratigraphical scheme of the Aalenian-Bajocian (lower Middle Jurassic) of the Pieniny Klippen Belt (after Wierzbowski et al., 2004; Segit, 2010)

The each bar (on the left) represents the inferred stratigraphical position of a section, while arrows show the maximum possible range as based on dinoflagellate cyst co-occurrences

tence of the Magura Basin located north of the "geoanticlinal Pieniny Zone"; later, Sikora (1971) postulated the existence of another basin located south of the Pieniny Succession where the Zlatne Succession, including the "black flysch" deposits of Cretaceous age was deposited.

According to Birkenmajer (1977, p. 145) "the Czorsztyn ridge... bordered the main Aalenian flysch trench of the Magura succession from the south...", but "...flysch aprons reached only slightly to the central trough (Czertezik, Niedzica and Branisko successions), possibly due to lateral supply from a distant eastern source...”. Krawczyk and Słomka (1986, pp 131, 132) assumed that "...the source areas of the Szlachtowa Fm. flysch were situated rather close to the place of flysch deposition..." and rare occurrences of current markings "...indicate two main transport directions from NE to SW (rarely from E to W) and from SE to NW..."; they thus concluded that "...the turbidity currents carried material from both the Czorsztyn geanticline area and unknown land situated along the northern margin of the basin..." (all the data come from the Szlachtowa Fm., east of Szczawnica). According to Birkenmajer (2007, p. 11) "the Czorsztyn Ridge most probably had an asymmetric structure: its the northern slope abruptly deepened and reached abyssal depth", and "fine clastic material was supplied from northern coast of the Ridge to the adjoining Magura (Grajcarek) Basin...in form of turbidites and submarine slumps (Szlachtowa Formation)". On the other hand (Oszczypko et al., 2004), postulated the uplift of the Czorsztyn Ridge during the Early Cretaceous which resulted in consequence in the formation of "black flysch" deposits in the Magura sub-Basin (to the north) and the Pieniny Klippen Belt sub-Basin to the south.

We accept the existence of only one deep basin bordering the Czorsztyn Ridge from the north - the pre-Late Albian Magura Basin ${ }^{1}$ (Figs. 12 and 13), and the development of a

\footnotetext{
${ }^{1}$ This new term is introduced herein to include an older part of the succession of deposits occurring within the Faklovka (or Šaris) Tectonic Unit, and below the sub-Pieniny and Pieniny tectonic units as interpreted by Oszczypko et al. (2010) and Plašienka and Mikuš (2010). The spatial and time relations between this part of the succession and that representing the Upper Cretaceous-Paleogene part of the Magura Succession are not clearly recognized.
} 


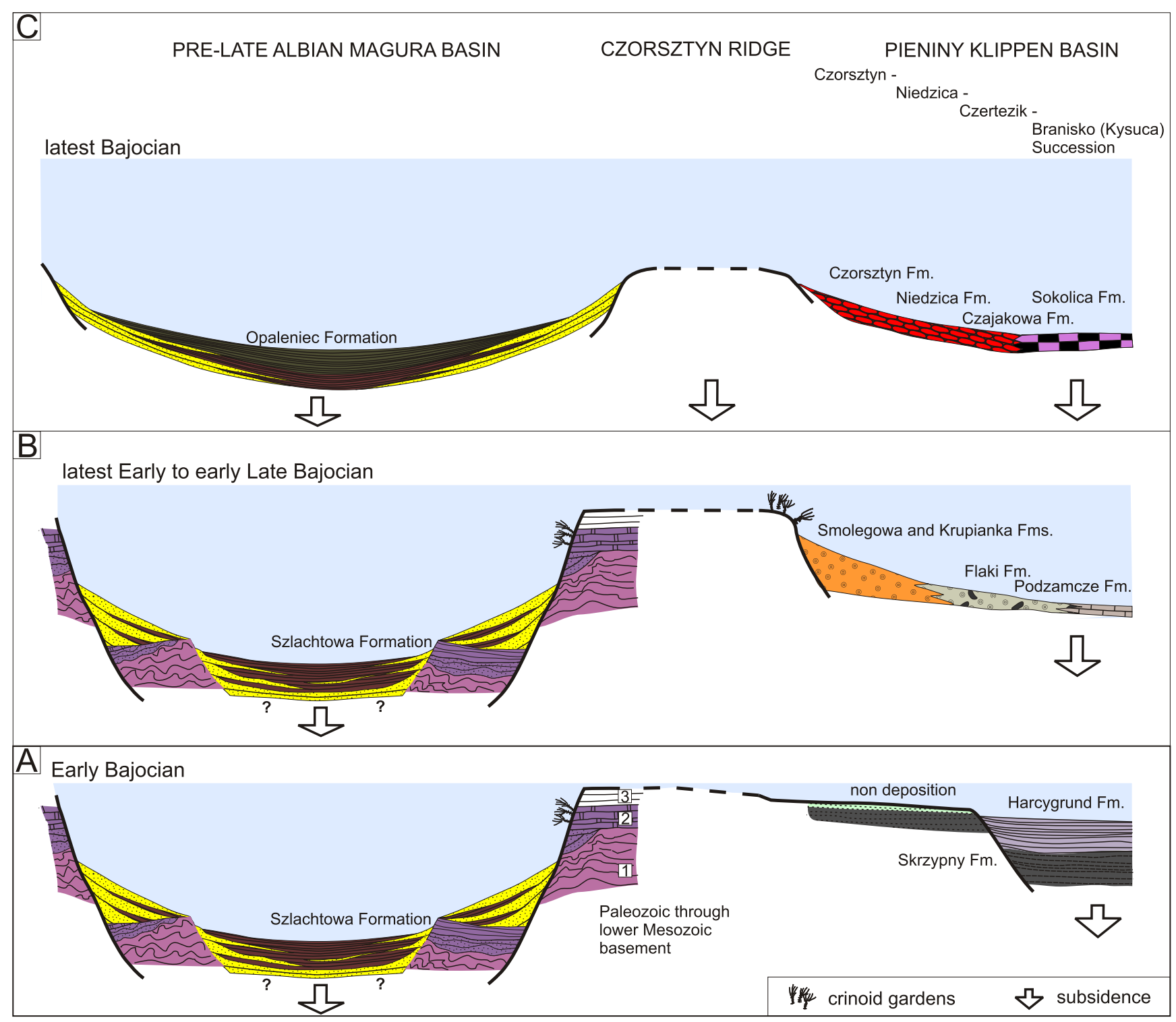

Fig. 13. Stages of the depositional evolution of the Pieniny Klippen Basin and pre-Late Albian Magura Basin in the Bajocian

Paleozoic through lower Mesozoic basement: 1- crystalline metamorphic substrate, 2- sandstones, shales and carbonates (Carboniferous to Lower Jurassic); 3 - hypothetical not recognized early Middle Jurassic deposits; Opaleniec Formation: black shales; for other explanations see Figure 12

steep northern slope of the Ridge which was possibly the source area for the materials redeposited to form the "black flysch" deposits during Early Bajocian as shown by dinoflagellate cyst assemblages in the sections studied. Rapid uplift of the Czorsztyn Ridge took place during the Early Bajocian as shown by ammonite faunas indicating a stratigraphical hiatus, and a marked change in sedimentation in the Czorsztyn-Niedzica-Czertezik successions of the Pieniny Klippen Basin south of the Czorsztyn Ridge (Krobicki and Wierzbowski, 2004; Wierzbowski et al., 2004). The southern, more gentle slope of the Czorsztyn Ridge inclined towards the Pieniny Klippen Basin, did not offer any possibility, however, for the development of "black flysch" deposits; there, smaller-scale tectonic scarps were settled by crinoid gardens which resulted at the end of the Early Bajocian in the formation of thick units of crinoidal limestones. According to this interpretation, the start of deposition of the "black flysch" deposits in the pre-Late Albian Magura Basin correlates with a stratigraphical hiatus and the beginning of sedimentation of crinoidal limestones in the Pieniny Klippen Basin - both resulting from uplift of the Czorsztyn Ridge.

The "black flysch" deposits that are rich in sandstones, as those studied in the Podubocze sections, are the most typical of the Szlachtowa Formation and were formed during the Early Bajocian. The succeeding deposits of late the Early Bajocian (Kamienka section) and the latest Early to early Late Bajocian age (Hałuszowa section) are, however, dominated by shales, and the turbidite intercalations occurring here are thinner and 
show a larger amount of crinoid ossicles, whereas the lithoclasts and mineral grains are smaller and subordinate. Although these deposits are also placed within the Szlachtowa Formation, they show some affinity to other deposits of the Magura Basin such as the Opaleniec Formation and the Stembrow Formation regarded as non-flysch deposits following deposition of the "black flysch" deposits (Birkenmajer, 1977; Gedl, 2008b). The onset of pelagic deposits both on the Czorsztyn Ridge (ammonitico-rosso) and south of it in the Pieniny Klippen Basin (radiolarites) during the latest Bajocian (Wierzbowski et al., 1999; Gedl, 2008b) indicates general subsidence of the ridge. The subsidence of the Czorsztyn Ridge resulted also in complete disappearance of "black flysch" deposits in the Magura Basin, at the end of the Bajocian.

This pattern of sedimentation possibly resulted from the opening of the pre-Late Albian Magura Ocean during the Early Bajocian and the related formation of the mid-oceanic Czorsztyn Ridge (see Krobicki and Wierzbowski, 2004, and earlier papers cited therein) which was followed by fast ocean spreading (Lewandowski et al., 2005).

Earlier development of the "black flysch" deposits in the pre-Late Albian Magura Basin during the Toarcian-Aalenian as regarded by some authors (see e.g., Gedl, 2008b; Birkenmajer et al., 2008; and earlier papers cited therein) seems rather improbable and these interpretations are based mostly on some dinoflagellate cysts and ammonites, as commented on below. Of the entire assemblage of dinoflagellate cysts treated as indicative of the Upper Toarcian and found in a few samples only in "black flysch" deposits (namely: in the Podubocze section; in an upper course of the Sztolnia Creek; in the Krupianka Creek; and at Grajcarek Jarmuta, see Gedl, $2008 b$, fig. 164) - none is indicative of the Toarcian, but all the assemblages consist of representatives of Nannoceratopsis and Kallospaeridium and indicate a stratigraphical interval from the Upper Toarcian to the Lower Bajocian. Concerning the ammonites referred to the "black flysch" facies, a considerable stratigraphical value was ascribed to those of Western Slovakia reported from the "Aalenian-Dogger complex" (Andrusov, 1929, p. 329), and treated as representing the Middle Jurassic flysch development ("Flyšový vývin doggeru" after Andrusov, 1945). These deposits, however, are developed either as dark gray shales with sandstone intercalations with quartz grains and mica flakes (typical development) or as shales with intercalations of crinoidal limestones (Andrusov, 1945, p. 40-42). The latter should not be included in the "black flysch" (Szlachtowa Formation), because they yielded neither sandstone layers nor mica-rich deposits; they represent the Pruské Succession - the special Pieniny Klippen Basin succession of Western Slovakia rich in crinoidal limestone intercalations in the ?Aalenian-Lower Bajocian interval (Segit, 2010; see also Aubrecht and Ožvoldová, 1994). Thus, the correlation of the ammonite findings of Andrusov $(1929,1945)$ with the "black flysch" facies as earlier accepted by Horwitz $(1933,1937)$ and repeated subsequently by many authors (e.g., Birkenmajer, 1977; Birkenmajer et al., 2008) seems unjustified. On the other hand, the Lower Aalenian ammonites of the genus Leioceras were described, from dark gray spotted limestone occurring within "black flysch" deposits attributed to the Grajcarek Unit in the Sztolnia Creek section (Birkenmajer and Myczyński, 1977; Birkenmajer et al., 2008). This unique occurrence is still the subject of debate (see Birkenmajer et al., 2008; and Gedl, 2008b, c, versus Oszczypko et al., 2004 and Oszczypko et al., 2008), and different stratigraphical and tectonical interpretations of the section are given. It should be remembered that a primary occurrence of the spotted limestone layer containing the Lower Aalenian ammonites within the "black flysch" succession is difficult to accept in the light of the stratigraphical interpretation presented herein, and more work is needed to resolve this apparent paradox (see also below).

The interpretation of the "black flysch" deposits as presented herein does not exclude, however, the occurrence of a separate "black flysch" unit of mid-Cretaceous age. There are significant palaeontological arguments in favour of the existence of such deposits (see Sikora, 1962; Blaicher and Sikora, 1969; Oszczypko et al., 2004), and their occurrence seems logical also from the palaeogeographical point of view. Uplift of the Czorsztyn Ridge during the Early Cretaceous has been demonstrated, and the ensuing erosion reached the Middle Jurassic (Aubrecht et al., 2006): on the other hand, redeposited material from the Ridge could be easily transported to the "Magura" Basin during the Albian-Cenomanian for such "black flysch" deposits to be formed (see Oszczypko et al., 2004, fig. 12). The latter - a "younger" flysch unit could also contain redeposited fragments of "older" Jurassic flysch, and this may explain the complex structure of some, also strongly tectonised, sections of "black flysch" in the Pieniny Klippen Belt, e.g., in the Sztolnia Creek section.

\section{CONCLUSIONS}

1. The "black flysch" of the Szlachtowa Formation at Podubocze near Czorsztyn is of Early Bajocian age, and similar deposits with subordinate sandstones at Kamienka and Hałuszowa are late Early to early Late Bajocian in age.

2. The Bajocian age of the "black flysch" in the area of study makes it difficult to attribute these deposits to the Pieniny Klippen Basin successions as accepted so far, but instead indicates their affiliation to the pre-Late Albian Magura Basin.

3. The occurrence of deposits of the pre-Late Albian Magura Basin Succession below the overthrusted deposits of the Klippen Basin (Czorsztyn Unit) in the area of study needs a marked change in the structural interpretation of the Pieniny Klippen Belt; it shows that deposits of the pre-Late Albian Magura Basin Succession represent the lowermost tectonic unit of the Pieniny Klippen Belt corresponding to the Faklovka Unit/Šariš Unit of Oszczypko et al. (2010) and Plašienka and Mikuš (2010).

4. Deposition of the "black flysch" deposits in the Early-early Late Bajocian was related to the origin of a fault-bounded basin, the southern margin of which constituted the Czorsztyn Ridge. 
Acknowledgements. The study has been supported by the Institute of Geology of the Faculty of Geology, University of Warsaw. The authors are grateful to the reviewers, N. Oszczypko, K. Pestchevitskaya and D. Plašienka, for their valuable comments. Admittance to protected areas of the Pieniny National Park is gratefully acknowledged.

\section{REFERENCES}

ANDRUSOV D. (1929) - Notes sur la géologie des Carpathes du Nord-Ouest. IV. Les Klippes piénines. Věstník Státního Geologického Ústavu Československé Republiky, 5-6: 327-342.

ANDRUSOV D. (1945) - Geologický výskum vnútorného bradlového pásma v Západných Karpatoch. Práce Štátneho Geologického Ústavu, 13: $1-176$.

AUBRECHT R. and OŽVOLDOVÁ L. (1994) - Middle Jurassic-Lower Cretaceous development of the Pruské Unit in the western part of the Pieniny Klippen Belt. Geol. Carpath., 45 (4): 211-223.

AUBRECHT R., KROBICKI M., SÝKORA M., MIŠIK M., BOOROVÁ D., SCHLÖGL J., ŠAMAJOVÁ E. and GOLONKA J. (2006) - Early Cretaceous hiatus in the Czorsztyn Succession (Pieniny Klippen Belt), Western Carpathians): submarine erosion or emersion. Ann. Soc Geol. Pol., 76: 161-196.

BARSKI M., MATYJA B.A. and WIERZBOWSKI A. (2010) - On the age of "black flysch" (Szlachtowa Formation) in the Podubocze sections near Czorsztyn, Pieniny Klippen Belt of Poland. Miner. Slovaca, 42 (4): 507.

BARSKI M., MATYJA B.A. and WIERZBOWSKI A. (2011a) - On some aspects of the detailed dinoflagellate cyst stratigraphy of the "black flysch” (Pieniny Klippen Belt of Poland). Grzybowski Found. Spec. Publ., 17: 70-71.

BARSKI M., MATYJA B.A., SEGIT T. and WIERZBOWSKI A. (2011b)O wieku tzw. „czarnego fliszu” (formacja szlachtowska) w Pieninach: nowe fakty a stare kontrowersje. Jurassica IX, Małogoszcz, 06-08. IX. 2011, materiały konferencyjne. Pol. Tow. Geol.: 72-75.

BIRKENMAJER K. (1953) - Preliminary revision of the stratigraphy of the Pieniny Klippen Belt series in Poland. Bull. Acad. Pol. Sc. Cl. 3, 1 (6): 271-274.

BIRKENMAJER K. (1957a) - Sedimentary characteristics of the Flysch Aalenian in the Pieniny Klippen belt (Central Carpathians). Bull. Acad. Pol. Sc., 3, 5 (4): 451-456.

BIRKENMAJER K. (1957b) - Monuments of inanimate nature in the Pieniny Klippen Belt. Part I: The gorge of the Dunajec valley between the castles of Czorsztyn and Niedzica (in Polish with English summary). Ochr. Przyr., R. 24: 157-178.

BIRKENMAJER K. (1963a) - Mapa geologiczna pienińskiego pasa skałkowego, ark. 6, Czorsztyn. Wyd. Geol.

BIRKENMAJER K. (1963b) - Stratigraphy and palaeogeography of the Czorsztyn Series (Pieniny Klippen Belt, Carpathians) in Poland (in Polish with English summary). Stud. Geol. Pol., 9.

BIRKENMAJER K. (1977) - Jurassic and Cretaceous lithostratigraphic units of the Pieniny Klippen Belt, Carpathians, Poland. Stud. Geol. Pol., 45.

BIRKENMAJER K. (1979) - Przewodnik geologiczny po pienińskim pasie skałkowym. Wyd. Geol., Warszawa.

BIRKENMAJER K. (2001) - Pieniny Klippen Belt. Introduction, 127-139. In: Carpathian Palaeogeography and Geodynamics: a Multidisciplinary Approach (eds. A. Paulo and M. Krobicki). Field trip guide, 12th Meeting of the Association of European Geological Societies, 10-15 September 2001, Kraków.

BIRKENMAJER K. (2007) - The Czertezik Succession in the Pieniny National Park (Pieniny Klippen Belt, West Carpathians): stratigraphy, tectonics, palaeogeography. Stud. Geol. Pol., 127: 7-50.

BIRKENMAJER K. and MYCZYŃSKI R. (1977) - Middle Jurassic deposits and fauna of the Magura Succession, near Szlachtowa, Pieniny Klippen Belt (Carpathians). Acta Geol. Pol., 27 (3): 387-400.

BIRKENMAJER K. and TURNAU E. (1962) - Carboniferous microspores as secondary deposits in the Aalenian Flysch of the Pieniny
Klippen Belt (Carpathians). Bull. Acad. Pol. Sc., Sér. Sc. géol. géogr., 10 (2): 99-103.

BIRKENMAJER K., GEDL P., MYCZYŃSKI R. and TYSZKA J. (2008) "Cretaceous black flysch" in the Pieniny Klippen Belt, West Carpathians: a case of geological misinterpretation. Cretaceous Res., 29: $535-549$.

BLAICHER J. and SIKORA W. (1969) - W sprawie wieku tzw. warstw ze Sztolni w pienińskim pasie skałkowym Polski. Kwart. Geol., 13 (3): 716-717.

BLAICHER J. and SIKORA W. (1972) - O nowej fliszowej facji albu w pienińskim pasie skałkowym Polski. Kwart. Geol., 16 (4): 1067-1068.

BRENNER W. and BIEBOW N. (2001) - Missing autofluorescence of recent and fossil dinoflagellate cysts - an indicator of heterotrophy? $\mathrm{N}$ Jb. Geol. Paläont. Abh., 219 (1): 229-240.

BURKHALTER R.M., BLÄSI H. R. and FEIST-BURKHARDT S. (1997) - Der Dogger B (oberes Aalénien) in den Bohrungen Herdern-1, Berlingen-1 und Kreuzlingen-1 (Nordschweiz) und seine Beziehungen zu den gleichaltrigen Schichten im Nordjura. Ecl. Geol. Helv., 90: 269-291.

DOLÁKOVÁ N. and BUREŠOVÁ A. (2007) - Use of fluorescent microscopy in the study of redeposited palynomorphs in the cave and marine sediments of Moravia (Czech Republic). Acta Palaeobot., 47 (1): 275-279.

FEIST-BURKHARDT S. (1990) - Dinoflagellate cyst assemblages of the Hausen coreholes (Aalenian to early Bajocian), southwest Germany. Bull. Centr. Rech. Expl.-Prod. Elf-Aquitaine, 14 (2): 611-633.

FEIST-BURKHARDT S. (1994) - Stratigraphic compilation of Below's data (1987a, 1987b and 1990) on Early and Middle Jurassic dinoflagellate cysts. Rev. Paléobiol., 13 (2): 313-318.

FEIST-BURKHARDT S. (2009) - Palynology of the Sinemurian/Pliensbachian boundary (Lower Jurassic) in the Wutach area, SW Germany: dinoflagellate cyst systematics, biostratigraphy and heterotrophic character of Liasidium variabile. N. Jb. Geol. Paläont. Abh., 254 (3): 293-313.

FEIST-BURKHARDT S. and MONTEIL E. (1997) - Dinoflagellate cysts from the Bajocian stratotype (Calvados, Normandy, Western France). Bull. Centr. Rech. Expl.-Prod. Elf-Aquitaine, 21 (1): 31-105.

FEIST-BURKHARDT S. and MONTEIL E. (2001) - Gonyaulacacean dinoflagellate cysts with multi-plate precingular archaeopyle. N. Jb. Geol. Paläont. Abh., 219 (1/2): 33-81.

FEIST-BURKHARDT S. and WILLE W. (1992) - Jurassic palynology in southwest Germany - state of the art. Cah. Micropaléont., 7 (1/2): $141-164$.

GEDL P. (2007) - Organic-walled dinoflagellate cysts from some Jurassic and Cretaceous strata of the Grajcarek Unit at Hałuszowa, Pieniny Klippen Belt (West Carpathians, Poland). Stud. Geol. Pol., 127: $101-117$.

GEDL P. (2008a) - The age of the Szlachtowa Formation (the co-called "black flysch") and the Opaleniec Formation (Pieniny Klippen Belt, Poland) based on dinoflagellate cyst studies (in Polish with English summary). Prz. Geol., 56 (3): 245-252.

GEDL P. (2008b) - Organic-walled dinoflagellate cyst stratigraphy of dark Middle Jurassic marine deposits of the Pieniny Klippen Belt, West Carpathians. Stud. Geol. Pol., 131: 7-227.

GEDL P. (2008c) - Głos w dyskusji nad biostratygrafią tzw. czarnego fliszu pienińskiego pasa skałkowego Polski. Prz. Geol., 56 (3): 212-220.

HORWITZ L. (1926) - Compte-redu des recherches géologiques exécutées en 1925 sur le territoire des feuilles "Szczawnica" et "Nowy 
Targ" (in Polish with French summary). Posiedz. Nauk. Państ. Inst. Geol., 14: 15-16.

HORWITZ L. (1933) - Compte-redu des recherches géologiques faites en 1932 pour la révision des feuilles de Nowy Targ et de Szczawnica de l'Atlas Géologiques de la Galicie (in Polish with French summary). Posiedz. Nauk. Państ. Inst. Geol., 35: 22-26.

HORWITZ L. (1937) - La faune et l'âge des couches á Posidonomyes (Zone Piénine des Klippes, Karpates Polonaises) (in Polish with French summary). Spraw. Państ. Inst. Geol., 8 (4): 69-127.

HORWITZ L. (1963) - Geological structure of the Pieniny Mts. Carpathians (in Polish with English summary). Pr. Inst. Geol., 38: $1-152$.

HORWITZ L. and RABOWSKI F. (1930) - Excursion dans les Piénines (Karpates Polonaises) de la Sociéte Géologique Polonaise (18-21.V.1929). Rocz. Pol. Tow. Geol., 6: 1-49.

JUREWICZ E. (1997) - The contact between the Pieniny Klippen Belt and Magura Unit (the Małe Pieniny Mts.). Geol. Quart., 41 (3): 315-326.

KRAWCZYK A.J. and SŁOMKA T. (1986) - Development and sedimentation of the Szlachtowa Formation (Jurassic Flysch) east of Szczawnica (Grajcarek Unit, Pieniny Klippen Belt, Carpathians) (in Polish with English summary). Stud. Geol. Pol., 88: 33-134.

KRAWCZYK A.J. and SŁOMKA T. (1987) - Exotic rocks from the Szlachtowa Formation (Jurassic flysch) of the Pieniny Klippen Belt, Carpathians (in Polish with English summary). Stud. Geol. Pol., 92 69-74.

KRAWCZYK A.J., MUSZYŃSKI M. and SŁOMKA T. (1987) - Exotic rock fragments from psammitic rocks of the Szlachtowa Formation (Jurassic flysch) of the Pieniny Klippen Belt, Carpathians (in Polish with English summary). Stud. Geol. Pol., 92: 75-86.

KROBICKI M. and WIERZBOWSKI A. (2004) - Stratigraphic position of the Bajocian crinoidal limestones and their palaeogeographic significance in evolution of the Pieniny Klippen Basin (in Polish with English summary). Tomy Jurajskie, 2: 69-82.

KSIA KIEWICZ M. (1972) - Karpaty. Budowa Geologiczna Polski, t. 4. Wyd. Geol., Warszawa.

LEWANDOWSKI M., KROBICKI M., MATYJA B.A. and WIERZBOWSKI A. (2005) - Palaeogographic evolution of the Pieniny Klippen Basin using stratigraphic and palaeomagnetic data from the Veliky Kamenets section (Carpathians, Ukraine). Palaeogeogr. Palaeoclimatol. Palaeoecol., 216: 53-72.

MALATA E. and OSZCZYPKO N. (2010) - How many "black flysches" can be distinguished in the Grajcarek thrust-sheets of the Pieniny Klippen Belt in Poland. Geol. Balcan., 39 (1-2): 239-240.

OSZCZYPKO N., MALATA E., ŠVÁBENICKÁ L., GOLONKA J. and MARKO F. (2004) - Jurassic-Cretaceous controversies in the Western Carpathian Flysch: the "black flysch" case study. Cretaceous Res., 25: 89-113.

OSZCZYPKO N., GOLONKA J. and MALATA E. (2008) - Odpowiedź na głos w dyskusji nad biostratygrafią tzw. czarnego fliszu pienińskiego pasa skałkowego w Polsce. Prz. Geol., 56 (3): 221-224.

OSZCZYPKO N., JUREWICZ E. and PLAŠIENKA D. (2010) - Tectonics of the Klippen Belt and Magura Nappe in the eastern part of the Pieniny Mts. (Western Carpathians, Poland and Slovakia) - new approaches and results. Sc. Ann., School of Geology, Aristotle University of Thessaloniki. Proceedings of the XIX CBGA Congress, Thessaloniki, Greece, Spec. vol., 100: 221-229.

PLAŠIENKA D. and MIKUŠ V. (2010) - Geologická stavba pieninského a šariškého úseku bradlového pásma medzi Litmanovou a Drienicou na východnom Slovensku. Miner. Slovaca, 42: 155-178.

POULSEN N.E. (1998) - Bajocian to Callovian (Jurassic) dinoflagellate cysts from central Poland. Acta Geol. Pol., 48: 237-245.
POULSEN N.E. and RIDING J.B. (2003) - The Jurassic cyst zonation of Subboreal Northwest Europe. Geol. Surv. Denm. Greenland Bull., 1: $115-144$.

POULSEN N.E., GUDMUNDSSON L., HANSEN J.M. and HUSFELDT Y. (1990) - Palynological preparation techniques, a new Maceratronik method and other modification. Danm. Geol. Unders., Series C, 10: $1-23$.

PRAUSS M. (1989) - Dinozysten-stratigraphie und Palynofazies im oberen Lias und Dogger von NW - Deutschland. Palaeontographica, Abt. B, 214 (1-4): 1-124.

RADKE M., SCHAEFER R.G., LEYTHAEUSER D. and TEICHMIILLER M. (1980) - Composition of soluble organic matter in coals: relation to rank and liptinite fluorescence. Geochim. Cosmochim. Acta, 44: 1787-1800.

RIDING J.B. and IOANNIDES N. (1996) - A review of Jurassic dinoflagellate cyst biostratigraphy and global provincionalism. Bull. Soc. Géol. France, 187: 3-14.

RIDING J.B. and THOMAS J.E. (1992) - Dinoflagellate cysts of the Jurassic system. In: A Stratigraphic Index of Dinoflagellate Cysts (ed. A.J. Powell): 7-57. Chapman and Hall, London.

SEGIT T. (2010) - Stratygrafia, zró nicowanie facjalne i środowisko sedymentacji aalenu i ni szego bajosu pienińskiego basenu skałkowego w wybranych profilach Polski i Słowacji. Unpubl. Ph.D. thesis. Faculty of Geology, University of Warsaw.

SIKORA W. (1962) - New data on the geology of the Pieniny Klippen Belt. Bull. Acad. Pol. Sc., Sér. géol. géogr., 10 (4): 203-211.

SIKORA W. (1971) - Esquisse de la tectogénèse de la zone des Klippes des Pieniny en Pologne d'après de nouvelles donnés géologiques. Rocz. Pol. Tow. Geol., 41 (1): 221-239.

STOVER L.E., BRINKHUIS H., DAMASSA S.P., de VERTEUIL L., HELBY R.J., MONTEIL E., PARTRIDGE A.D., POWELL A.J., RIDING J.B., SMELROR M. and WILLIAMS G.L. (1996) - Mesozoic-Tertiary dinoflagellates, acritarchs and prasinophytes. AASP Found., 2: 641-750.

TYSON R.V. (1993) - Palynofacies analysis. In: Applied Micropalaeontology (ed. D.J. Jenkins): 153-191. Kluwer: Dordrecht.

TYSZKA J. (1995) - Mid-Jurassic palaeoenvironment and benthic communities in the Klippen and Magura Basins, Pieniny Klippen Belt, Poland. Unpubl. Ph.D. thesis. Institute of Geological Sciences, Polish Academy of Sciences, Kraków.

Van GIJZEL P. (1967) - Palynology and flurescence microscopy. Rev. Palaeobot. Palynol., 2: 49-79.

Van GIJZEL P. (1971) - Review of the UV - fluoscence microphotometry of fresh and fossil exines and exosporia. In: Sporopollenin (eds. J. Brooks, P.R. Grant, M.D. Muir, et al.,): 659-685. London, Academic Press.

Van GIJZEL P. (1981) - Appllications of the geomicrophotometry of kerogen, solid hydrocarbons and crude oils to petroleum exploration. In: Organic Maturation Studies and Fossil Fuel Exploration (ed. J. Brooks): 351-377. London, Acad. Press.

WIERZBOWSKI A., JAWORSKA M. and KROBICKI M. (1999) - Jurassic (Upper Bajocian-lowest Oxfordian) ammonitico rosso facies in the Pieniny Klippen Belt, Carpathians: its fauna, age, microfacies and sedimentary environment. Stud. Geol. Pol., 115: 7-74.

WIERZBOWSKI A., AUBRECHT R., KROBICKI M., MATYJA B.A. and SCHLÖGL J. (2004) - Stratigraphy and palaeogeographic position of the Jurassic Czertezik Succession, Pieniny Klippen Belt (Western Carpathians) of Poland and Eastern Slovakia. Ann. Soc. Geol. Pol., 74 (3): 237-256.

WOOLLAM R. and RIDING J.B. (1983) - Dinoflagellate cyst zonation of the English Jurassic. Inst. Geol. Sc. Rep., 83 (2): 1-41. 